\title{
Lake browning impacts community structure and essential fatty acid content of littoral invertebrates in boreal lakes
}

\author{
Petri Kesti (i) - Minna Hiltunen (i) - Ursula Strandberg ( J J Jussi Vesterinen (1) \\ Sami Taipale (i) Paula Kankaala $($ i)
}

Received: 15 April 2021/Revised: 25 October 2021/Accepted: 6 November 2021/Published online: 22 November 2021

(C) The Author(s) 2021

\begin{abstract}
Many lakes in the northern hemisphere are browning due to increasing concentrations of terrestrial dissolved organic carbon (DOC). The consequences of lake browning to littoral invertebrates, however, are not fully understood. We analyzed community structure and fatty acid (FA) profiles of littoral invertebrates in humic (DOC-rich) and clear-water lakes in Eastern Finland. We found higher abundance of chironomids (Diptera: Chironomidae) in humic compared to clearwater lakes, whereas stoneflies (Plecoptera) and mayflies (Ephemeroptera: Baetidae) were more abundant in clear-water lakes. Taxon explained $65 \%$ of the differences in the FA composition of littoral invertebrates. However, the proportion and content of
\end{abstract}

Supplementary Information The online version contains supplementary material available at https://doi.org/10.1007/ s10750-021-04760-1.

Handling Editor: Maria de los Angeles Gonzalez Sagrario

P. Kesti $(\bowtie) \cdot$ U. Strandberg · J. Vesterinen .

P. Kankaala

Department of Environmental and Biological Sciences,

University of Eastern Finland, Joensuu, Finland

e-mail: petri.kesti@uef.fi

M. Hiltunen · S. Taipale

Department of Biological and Environmental Science,

University of Jyväskylä, Jyväskylä, Finland

J. Vesterinen

The Association for Water and Environment of Western

Uusimaa, P.O. Box 51, 08101 Lohja, Finland polyunsaturated FAs of several taxa were significantly higher in clear-water lakes compared to humic lakes. Our results reveal differences in both community structure and nutritional quality of littoral invertebrates for fish between humic and clear-water lakes.

Keywords Polyunsaturated fatty acids - Benthic invertebrates $\cdot$ Terrestrial organic matter $\cdot$ Asellus aquaticus $\cdot$ Chironomidae

\section{Introduction}

Lake browning, due to increased concentrations of terrestrial dissolved organic carbon (DOC) and iron, has been observed in many regions in the northern hemisphere during the recent decades (e.g., Monteith et al., 2007; Weyhenmeyer et al., 2014). This phenomenon has been related to catchment soil recovery from acidification, climate change, increased precipitation and runoff, and shortened soil frost period (e.g., Hongve et al., 2004; Lepistö et al., 2014; Kritzberg, 2017). Together with anthropogenic loads of terrestrial-derived detritus via intensified land-use practices, e.g., clear-felling of forests from peatland catchments, the load of DOC is expected to rise in the future (e.g., Nieminen et al., 2015; Hayden et al., 2017).

Lake browning has many ecological consequences on lake food webs, especially via impairing the light 
regime for primary producers (Thrane et al., 2014; Bergström \& Karlsson, 2019). In addition to e.g., lake size and habitat richness, environmental factors, such as water temperature, oxygen concentration, and lake trophic state, have been shown to affect the invertebrate community structure and the availability of their food sources (Lau et al., 2013; Jyväsjärvi et al., 2014; Gladyshev et al., 2016). Brown lakes (referred hereafter as humic lakes) differ from clear-water lakes in both physical and chemical characteristics. Humic lakes are generally more acidic and can suffer from wintertime oxygen deficiency (Luoto, 2013). Acidity is one of the factors affecting the littoral invertebrate assemblages. Phantom midges (Diptera: Chaoboridae) are characteristic in strongly acidic lakes, whereas gammarids (Amphipoda: Gammaridae) and some mayflies (Ephemeroptera) are limited to weakly acidic lakes (Walker et al., 1985). Oxygen deficiency is also harmful for e.g., Ephemeroptera and Plecoptera (Fochetti \& Tierno De Figueroa, 2008). Some UVsensitive species, like phantom midges from the genus Chaoborus, might benefit from lake browning since it shelters them from excessive UV radiation (Lindholm et al., 2018).

Certain polyunsaturated fatty acids (PUFAs) are considered essential fatty acids (EFAs) for many consumers. Traditionally, $\alpha$-linolenic acid (ALA,

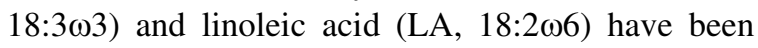
considered the only EFAs since they are the precursors of long-chain PUFAs (LCPUFAs, $\geq 20 \mathrm{C}$ PUFAs). The bioconversion efficiency from ALA to eicosapentaenoic acid (EPA, 20:5 13 ) and docosahexaenoic acid

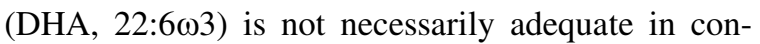
sumers, and thus EPA and DHA can be considered as the physiologically most EFAs (Sargent et al., 1995).

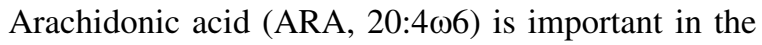
development of fish eggs (Sargent et al., 1999) but its importance for littoral invertebrates is unclear (Ahlgren et al., 2009). In addition to individual EFAs, the $\omega 3 / \omega 6$ ratio in consumers may be important (Ahlgren et al., 2009; Arts \& Kohler, 2009), and the latter is also used to identify allochthonous vs. autochthonous food sources (Torres-Ruiz et al., 2007; Guo et al., 2016).

In aquatic ecosystems, EFAs are mainly synthesized by algae. Different algal communities have characteristic FA compositions, and EPA and DHA are synthesized by specific algal taxa. Chlorophytes contain high amounts of ALA and LA (Taipale et al., 2013), whereas diatoms, cryptophytes, and chrysophytes synthesize
EPA and dinoflagellates DHA (Ahlgren et al., 1990; Taipale et al., 2013; Galloway \& Winder, 2015). Terrestrial material, e.g., plant leaves, contain mainly saturated fatty acids (SAFAs), especially $>\mathrm{C}_{22}$ SAFAs (Brett et al., 2009; Bec et al., 2010; Taipale et al., 2014). Impacts of lake browning on EFA production in aquatic ecosystems are mostly related to the variation in algal community structure (Gutseit et al., 2007; Taipale et al., 2016; Strandberg et al., 2020b). Moreover, climate change induced increase in annual water temperature and duration of growing season are predicted to benefit cyanobacteria (Anneville et al., 2015; Senar et al., 2021), which are not a good quality food source for consumers in terms of EFAs (Müller-Navarra et al., 2000; Martin-Creuzburg et al., 2008). Additionally, lake browning increases bacterial activity and shifts the dominance of primary production from benthic to pelagic zone via decreased light penetration (Ask et al., 2012; Vasconcelos et al., 2019).

Recently, our knowledge on FA profiles of benthic invertebrates in the northern hemisphere has increased markedly (Sushchik et al., 2003; Makhutova et al., 2011, 2016; Lau et al., 2012, 2013; Vesterinen et al., 2020). FA composition seems to be quite conserved in littoral invertebrate taxa, and phylogeny is the most important factor determining it (e.g., Sushchik et al., 2003; Makhutova et al. 2011; Lau et al., 2012; Vesterinen et al., 2020). Many littoral invertebrates are important food sources for fish (Sushchik et al., 2003; Makhutova et al., 2011). Reported favorable food sources include larvae of black flies (Diptera: Simuliidae), caddisflies (Trichoptera), and Chironomidae, and the nymphs of Plecoptera and Ephemeroptera (Khrennikov et al., 2007; Shustov et al., 2012).

In this study, we analyzed littoral invertebrate (referred hereafter as invertebrate) community data from a total of 26 lakes in Eastern Finland to investigate potential differences in the community structure of invertebrates between humic and clearwater lakes. Additionally, we analyzed the FA composition of common invertebrates from 10 lakes in Eastern Finland differing in DOC concentration. Our aim was to study the effects of lake type (humic vs. clear-water) and littoral shore type (vegetated vs. unvegetated) on the FA composition and content of invertebrates.

We hypothesized that the invertebrate communities differ between humic and clear-water lakes because of 
differences in physical and chemical factors (e.g., DOC concentration, $\mathrm{pH}$ ) and biological factors (e.g., algal community structure) between lake types. Secondly, we hypothesized that invertebrates inhabiting humic lakes have a lower PUFA content compared to the ones inhabiting clear-water lakes. Our third hypothesis was that invertebrates differ in their FA composition depending on the type of littoral shore they inhabit since different shore types harbor varying food sources (Smock \& Harlowe, 1983; Jones et al., 1998).

\section{Materials and methods}

Invertebrate community analyses

We retrieved data on invertebrate community structure from the Finnish Environment Institute (SYKE) HERTTA-database (www.syke.fi/avoindata). The data has been collected as a part of monitoring for the Water Framework Directive (WFD) by the Centre for Economic Development, Transport, and the Environment (ELY Centre) of North Karelia. We retrieved data for a total of 26 lakes located in Eastern Finland (16 humic and 10 clear-water lakes). We selected our lakes based on WFD lake type (humus-rich and humus-poor lakes), size ( $\left.\geq 1 \mathrm{~km}^{2}\right)$, and sampling method (handnet). Clear-water lakes had low concentrations of total organic carbon (TOC), total nitrogen (TN), and total phosphorus (TP) (range, TOC $=2.9-8.9 \mathrm{mg} \mathrm{l}^{-1}, \quad \mathrm{TN}=160.0-461.0 \mu \mathrm{g} \mathrm{l}^{-1}$, $\mathrm{TP}=2.1-9.4 \mu \mathrm{g}^{-1}$ ) whereas humic lakes had higher TOC, TN, and TP (range, TOC $=12.5-25.0 \mathrm{mg} \mathrm{l}^{-1}$, $\left.\mathrm{TN}=314.9-768.2 \mu \mathrm{g} \mathrm{l}^{-1}, \quad \mathrm{TP}=9.2-40.0 \mu \mathrm{g} \mathrm{l}^{-1}\right)$, respectively. Eutrophic lakes $\left(\mathrm{TP}>50 \mu \mathrm{g} \mathrm{l}^{-1}\right.$ ) were excluded from the analyses. Invertebrate data was retrieved from the database in December 2018, and physical and chemical characteristics were retrieved in November 2019. Lake characteristics are presented in Supplementary Information (SI), Table S1. We compared the average abundance of different invertebrate taxa between the lake types. Only those taxa with an average abundance of $\geq 0.5 \%$ of the total invertebrates in either of the lake types were included.
Lakes for the fatty acid analyses

Terrestrial DOC influence on FA composition and content in different food web compartments was studied in 10 lakes in the same region studied for the invertebrate community composition (see above). The selected lakes consisted of four clear-water lakes with low concentrations of DOC, TN, and TP (range, DOC $=2.8-7.9 \mathrm{mg} \mathrm{l}^{-1}, \quad \mathrm{TN}=169.3-365.3 \mu \mathrm{g} \mathrm{l}^{-1}$, and $\mathrm{TP}=1.6-4.9 \mu \mathrm{g} \mathrm{l}^{-1}$ ), and six humic lakes with higher concentrations of DOC, TN, and TP (range, $\mathrm{DOC}=11.9-18.7 \mathrm{mg} \mathrm{l}^{-1}, \mathrm{TN}=285.5-629.2 \mu \mathrm{g} \mathrm{l}^{-1}$, and TP $=11.1-28.8 \mu \mathrm{g} \mathrm{l}^{-1}$ ), respectively. Lake characteristics are presented in SI, Table S2. For more detailed description for catchment characteristics, lake water chemistry and for results on phytoplankton and predatory fish see Strandberg et al. (2016, 2020b).

Invertebrate sampling and selection

Invertebrates were collected with a standardized kicknet sampling method from two different shore types, vegetated and unvegetated, in July-September 2013. Coordinates of the sampling sites are presented in SI, Table S3. Invertebrates were collected on a $0.5 \mathrm{~mm}$ mesh-sized sieve in the field and transferred to buckets. Afterwards the samples were sorted in the laboratory and stored in Eppendorf tubes at $-18{ }^{\circ} \mathrm{C}$ until further analyses in 2017. Identification of the taxa was done to the genus or species level, when possible. In the laboratory, samples were briefly thawed, rinsed with MilliQ, and frozen and freeze-dried with Christ ALPHA 1-4 LDplus (Martin Christ Gefriertrocknungsanlagen $\mathrm{GmbH}$, Osterode, Germany). Six different taxa were selected for the FA analyses (SI, Table S4): water mites (Acari: Hydracarina), spreadwinged damselflies (Zygoptera: Lestes), Ephemeroptera (Heptagenia), Chironomidae, cladocera (Cladocera: Sida), Asellus (Crustacea: Asellus aquaticus; Linnaeus, 1758, referred hereafter as Asellus), and amphipods (Amphipoda: Pallasea quadrispinosa; Sars, 1867, referred hereafter as Pallasea), present only in clear-water lake samples. When present in the samples, 1-4 subsamples of each taxa were analyzed for both shore types in each lake, consisting of several individuals (2-20) to get the desired sample weight (1-2 mg dry weight). Mean values for specific taxa in each lake and/or shore type were used in statistical analyses. The invertebrates selected for the FA 
analyzes represent different functional feeding guilds. Hydracarina is a taxonomically diverse group, and their adult forms are mainly predatory (Di Sabatino et al., 2000). Lestes, like other dragonfly larvae, are also predators. Chironomids are opportunistic feeders, many are detritivores, ingesting different kinds of particles from the sediments, but a wide variety of feeding guilds are found in this family (Reuss et al., 2013). A previous study has indicated that the community structure of Chironomidae differs between the clear-water and humic lakes (Luoto, 2013), which is also reflected in the feeding guilds (Kivilä et al., 2019). In our study, it was necessary to pool several chironomid individuals for FA analyses, and thus, these could be identified only at family level. Heptageniidae are classified as collectors/scrapers, and they utilize surface periphyton as their main food source (Cummins, 1973), but species from the genus Heptagenia perform mixed feeding, categorizing them as shredders/grazers. Asellus are shredders/grazers who utilize detritus and epilithic algae (Moog, 2002), but they are also generalists (Lau et al., 2013). Sida are filter feeders, who attach to the surfaces of aquatic vascular plants (Fairchild, 1981). Pallasea are omnivorous, feeding on both algae and smaller invertebrates (Hill, 1988).

Fatty acid analysis

Freeze-dried invertebrates were pulverized with mortar and pestle and 1-2 mg of pulverized tissue were weighed for the FA extraction. The extraction was done by extracting the lipids twice with a 2:1 (volume) chloroform:methanol following Folch et al. (1957). For gas chromatography (GC), the FAs were turned into FA methyl esters (FAMEs) using an acidcatalyzed transesterification reaction with $1 \% \mathrm{H}_{2} \mathrm{SO}_{4}$ in methanol (Christie, 1993). FAMEs were dissolved in hexane and analyzed with a gas chromatograph (Agilent 6890N, Agilent Technologies, Wilmington, DE, USA) equipped with a mass selective spectrometer (Agilent 5973N). The column we used was an Agilent DB-23 $(0.25 \mathrm{~mm} \times 30 \mathrm{~m} \times 0.25 \mu \mathrm{m})$. Helium was used as a carrier gas and the flow rate was $37 \mathrm{~cm} \mathrm{~s}^{-1}$. The GC temperature program was as follows: The starting temperature was $50{ }^{\circ} \mathrm{C}$ for $1 \mathrm{~min}$, after which raised from 50 to $150{ }^{\circ} \mathrm{C}$ at $15^{\circ} \mathrm{C} \mathrm{min}{ }^{-1}$, then to $190{ }^{\circ} \mathrm{C}$ at $1.5^{\circ} \mathrm{C} \mathrm{min}{ }^{-1}$, then to $210{ }^{\circ} \mathrm{C}$ at $2{ }^{\circ} \mathrm{C} \min ^{-1}$. The final temperature was held for $15 \mathrm{~min}$. The total running time for samples was $59.33 \mathrm{~min}$. SAFA 21:0 (heneicosanoic acid) (NuChek Prep., Elysian, MN, USA) was used as an internal standard, and GLC-68E (Nu-Chek Prep.) was used for the calibration. Mass spectra and GLC-68E were used for the identification of FAMEs.

\section{Statistical analyses}

Non-metric multidimensional scaling (NMDS) was used to visualize the variation in invertebrate community structure between humic and clear-water lakes and the differences in the FA composition between invertebrates according to three factors: species identity (taxon), lake type (humic vs. clear-water), and shore type (vegetated vs. unvegetated). NMDS ordinations were based on Euclidean distance. We used stress values to describe how well the ordination described our original data. Stress values $<0.2$ were considered acceptable, whereas stress values $>0.2$ were considered random ordinations (Clarke, 1993). Abundances of invertebrate taxa in a lake community and the FA proportions of invertebrates were arcsine square-root transformed. We performed permutational multivariate analysis of variance (PERMANOVA) to investigate the effect of lake type on the invertebrate community structure. Lake-type was treated as fixed factor, with two levels: clear-water and humic lakes. Additionally, we used PERMANOVA to analyze the taxon, lake type-, and shore type-specific differences in the FA composition of invertebrates. Taxon and lake type were treated as fixed factors. Taxon had seven levels, i.e., taxonomic groups: Hydracarina, Heptagenia, Chironomidae, Lestes, Sida, Asellus, and Pallasea. Lake-type had two levels: humic and clearwater lakes. Shore-type was nested in lake type. We ran an unconstructed permutation of raw data using type III sum of squares. We also ran pair-wise test to investigate the differences for each taxon between lake and shore-types and possible interactions. Similarity percentage (SIMPER) was used to see more specifically which FAs were responsible for the differences in the FA composition.

We further investigated the effects of specific environmental factors on the invertebrate FA composition. We used distance-based linear modeling (DistLM) to evaluate how much of the variation in the FA composition of invertebrates could be explained by different lake characteristics. These 
characteristics included e.g., lake area, mean depth, concentrations of Chl $a$, TP, TN, and DOC, and percentage of peatland in the lake catchment area. A full list of the analyzed lake characteristics for the FA composition is presented in SI, Table S2. We used a stepwise selection of environmental factors with adjusted $R^{2}$ as model selection criteria.

We also compared the proportion and content of FAs between humic and clear-water lakes in our invertebrates. In addition, we calculated the $\omega 3 / \omega 6$ and DHA/ARA ratio of invertebrates, as their optimal ratios are important for normal growth and development of invertebrates (Makhutova et al., 2011). We used Student's $t$-test and ANOVA (Tukey post hoc test) to test the differences between FA composition, and $\omega 3 / \omega 6$ and DHA/ARA ratio of invertebrates. NMDS, PERMANOVA, SIMPER, and DistLM analyzes were done with Primer 6 and Permanova+ program package (PRIMER-E Ltd, Plymouth, UK). Other statistical analyzes were done with IBM SPSS Statistics 25 program package (IBM Corp., Armonk, New York, USA).

\section{Results}

Invertebrate community structure

The most common invertebrates in humic lakes were Chironomidae, Asellidae, and Ephemeroptera (Leptophlebiidae), and in clear-water lakes Asellidae, Coleoptera (Elmidae), and Chironomidae, respectively (SI, Table S5). We found a significant difference in the invertebrate community structure between the two lake types at family level (PERMANOVA, Pseudo$F=2.4013, p<0.01$ ) (Fig. 1). Taxa contributing the most to the differences between the two lake types were Asellidae (21\%), Chironomidae (15\%), and Leptophlebiidae (10\%) (SIMPER). Taxa and their contribution to the differences between the two lake types are listed in Table 1. When relative abundances were compared between the lake types, Chironomidae were significantly more abundant in humic lakes compared to clear-water lakes ( $t$-test, $t=2.773, \quad \mathrm{df}=24$, $P<0.05)$, whereas Plecoptera as a whole ( $t$-test, $t=-2.263, \quad \mathrm{df}=24, \quad P<0.05), \quad$ Ephemeroptera (Baetidae: $t=-3.943$, df $=24, P<0.05$ ), and Plecoptera (Capniidae: $t=-2.162$, df $=24, P<0.05$ ) were significantly more abundant in clear-water lakes compared to humic lakes. We also found that certain families from Amphipoda (Pallaseidae) and Trichoptera (Hydropsychidae) were completely absent from humic lakes (SI, Table S5).

Fatty acid composition of invertebrates

We identified a total of 61 different FAs in our invertebrate samples from 10 lakes. FAs with an average proportion of $\geq 0.5 \%$ of total FAs in at least one of the taxa are presented in Table 2. Pallasea had a significantly higher DHA/ARA ratio and proportion of DHA (Tukey post hoc, $P<0.001$ ) compared to the other taxa (Table 2). There were also significant differences in the overall FA composition between invertebrates (PERMANOVA, Pseudo- $F=33.762$, $P<0.001$ ) (Fig. 2). Taxa accounted for $65 \%$ of the differences in the FA composition of invertebrates (PERMANOVA).

Effects of lake characteristics on FA composition of invertebrates

Lake type significantly affected the FA composition of Chironomidae $\quad(t=2.1696, \quad P<0.01), \quad$ Sida $(t=2.4778, \quad P<0.05)$, and Asellus $(t=4.6496$, $P=0.0001)$ (PERMANOVA pair-wise tests). Lake type alone accounted for only $5 \%$ of the differences in the FA composition of invertebrates, and lake type and taxa in combination accounted for $10 \%$ (PERMANOVA). The FAs contributing the most to the differences between the two lake types in our invertebrates were: Hydracarina: LA (18\%), Chironomidae: EPA (13\%), Heptagenia: ALA (17\%), Lestes:

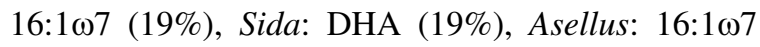
(57\%) (SIMPER) (Table 3). FAs which contributed at least $10 \%$ of the differences in the invertebrate FA composition between humic and clear-water lakes are presented in Table 3. More complete list of the FAs is presented in SI, Table S6, respectively.

In many taxa, the relative proportions of summed monounsaturated FAs (MUFA), SAFA and PUFA differed between the two lake types (Table 2). The proportion of PUFAs was significantly higher in clearwater lakes compared to humic lakes in Chironomidae, Sida, Lestes, and Asellus ( $t$-test, Chironomidae: $t=-2.911$, df $=14, P<0.05$. Sida: $t=-3.087$, df $=8, P<0.05 ;$ Lestes: $t=2.927, \mathrm{df}=18, P<0.01$; Asellus, $t=-5.032$, df $=25, P<0.001$ ) (Fig. 3). 


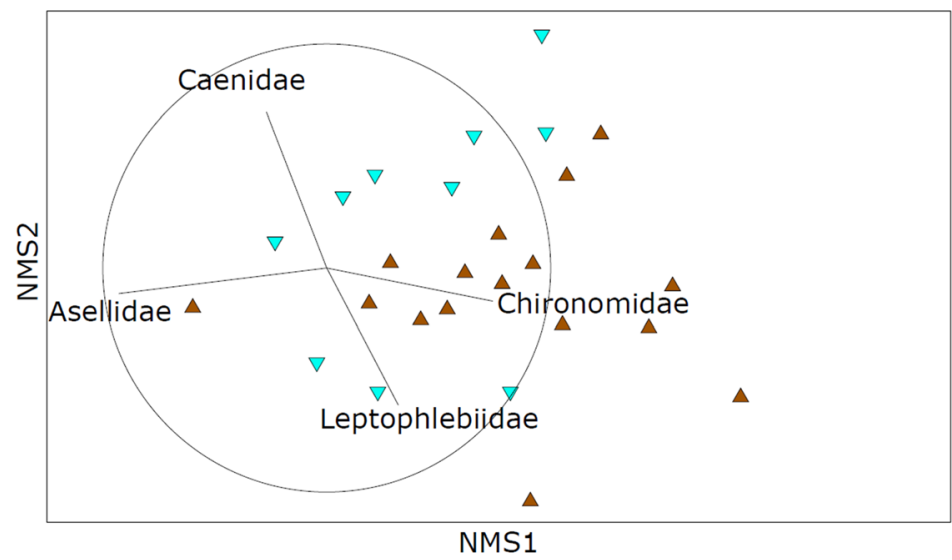

$\triangle$ Humic
$\nabla$ Clear-water

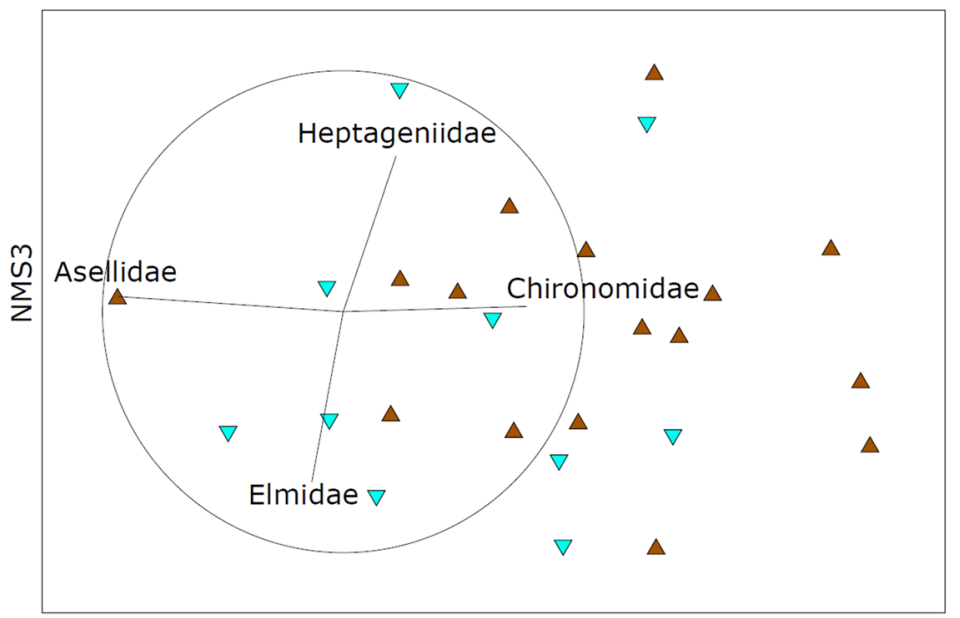

Increase of DOC

Fig. 1 Non-metric multidimensional scale (NMDS) ordinations of the littoral invertebrate community composition in humic and clear-water lakes at the family level. Samples from humic lakes are presented as brown and samples from clear-water lakes as light blue triangles, respectively. The ordinations were based on

Lake type also had a significant effect on the $\omega 3 / \omega 6$ and/or DHA/ARA ratio of these four taxa. The $\omega 3 / \omega 6$ ( $t$-test: Chironomidae, $\quad t=-3.745, \quad \mathrm{df}=14$, $P<0.005$; Lestes, $t=-3.563$, df $=18, P<0.005$; Asellus, $t=-2.443$, df $=25, P<0.05)$ and the DHA/ARA ratio ( $t$-test: Sida, $t=-4.160$, df $=8$, $P<0.005$; Asellus, $t=-4.162$, df $=25, P<0.001$ ) were significantly higher in clear-water lakes (Table 2 ). We could not compare the FA composition or ratios of Pallasea between the two lake types because all samples came from clear-water lakes.
Euclidean distance. Littoral invertebrate families that correlate strongly (Pearson $r>0.6$ ) with either of the axes are visualized with vectors. The $3 \mathrm{D}$ stress value for the ordination was 0.11 . The amount of DOC increases towards the right side of the ordinations

Shore type did not have significant effects on the FA composition of invertebrates, except for Heptagenia (PERMANOVA Pseudo- $F=22.638, P<0.001$ ). This difference, however, was statistically significant only in humic lakes (PERMANOVA pair-wise tests, $t=4.9824, P<0.01)$. The FAs contributing the most to the differences between the two shore types in

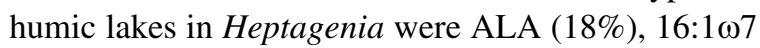
(14\%), and 16:0 (12\%) (SIMPER). ALA was generally more common in unvegetated shores, whereas 16:1 107 and 16:0 were more common in vegetated shores. 
Table 1 Proportions and standard deviations of different invertebrate families and their contributions to the dissimilarities of invertebrate communities between humic and clear-water lakes (SIMPER)

\begin{tabular}{|c|c|c|c|c|}
\hline Taxa & $\begin{array}{l}\text { Proportion (\%) } \\
\text { Humic }\end{array}$ & Clear-water & Contribution to dissimilarity (\%) & Cumulative contribution $(\%)$ \\
\hline Asellidae & $17.0 \pm 14.2$ & $22.7 \pm 15.8$ & 21 & 21 \\
\hline Chironomidae & $22.2 \pm 10.8$ & $9.4 \pm 7.4$ & 15 & 36 \\
\hline Leptophlebiidae & $11.9 \pm 8.2$ & $6.2 \pm 8.2$ & 10 & 45 \\
\hline Elmidae & $5.4 \pm 6.0$ & $10.0 \pm 8.2$ & 9 & 54 \\
\hline Heptageniidae & $9.6 \pm 10.0$ & $6.9 \pm 5.6$ & 6 & 61 \\
\hline Caenidae & $4.7 \pm 4.0$ & $7.4 \pm 5.7$ & 6 & 66 \\
\hline Ceratopogonidae & $4.8 \pm 3.7$ & $5.9 \pm 4.2$ & 5 & 72 \\
\hline Capniidae & $0.0 \pm 0.1$ & $1.9 \pm 3.5$ & 4 & 76 \\
\hline Pallaseidae & $0.0 \pm 0.0$ & $1.8 \pm 2.5$ & 4 & 79 \\
\hline Corixidae & $1.6 \pm 4.3$ & $0.3 \pm 0.5$ & 3 & 82 \\
\hline Baetidae & $0.2 \pm 0.2$ & $1.8 \pm 2.2$ & 3 & 85 \\
\hline Lepidostomatidae & $2.1 \pm 3.0$ & $1.8 \pm 1.3$ & 3 & 87 \\
\hline Psychomyiidae & $1.8 \pm 2.1$ & $1.8 \pm 1.5$ & 2 & 90 \\
\hline Limnephilidae & $0.6 \pm 1.2$ & $1.2 \pm 2.1$ & 2 & 92 \\
\hline
\end{tabular}

In combination, different physical and chemical parameters explained 37-92\% of the FA composition of our invertebrates (DistLM). The most important parameters to explain the FAs were: for Hydracarina and Asellus: organic carbon to total nitrogen $(\mathrm{C} / \mathrm{N})$ ratio of the lake water (Hydracarina 17\%, Asellus $56 \%$ ), for Chironomidae: Secchi depth (25\%), for Heptagenia: lake area as percentage of catchment (15\%), for Sida and Lestes: Mean depth of the lake $\left(D_{\text {mean }}\right)$ (Sida 53\%, Lestes 21\%) (DistLM). Statistically significant factors and their proportion explaining the FA composition of invertebrates are presented in Table 4, and a more complete list of the factors is presented in SI, Table S7, respectively.

Effects of lake characteristics on FA content of invertebrates

The total FA content (per dry weight, DW) of invertebrates ranged from 29.5 to $234.9 \mu \mathrm{g} \mathrm{mg} \mathrm{DW}^{-1}$. On average, the total FA content $\left(\mu \mathrm{g} \mathrm{mg} \mathrm{DW}^{-1}\right)$ was: Hydracarina: $132.2 \pm 70.7$, Heptagenia: $140.0 \pm 42.5$, Lestes: $153.4 \pm$ 68.1, Chironomidae: $72.4 \pm 32.1$, Sida: $80.7 \pm 20.9$, Asellus: $132.5 \pm 69.4$, and Pallasea: $133.8 \pm 49.2$. The average FA content of invertebrates in humic and clear-water lakes is presented in Table 2 and lake specific FA content is presented in SI, Table S8, respectively. Lake type significantly influenced the total FA content of Heptagenia and Asellus. In Heptagenia, the
FA content was significantly higher in clear-water lakes $(t$ test, $t=-2.581, \mathrm{df}=14, P<0.05)$. In Asellus the total FA content was significantly higher in humic lakes ( $t$-test, $t=3.499$, df $=25, P<0.005)$, which was mainly due to their high MUFA and SAFA content. In Chironomidae and Sida the PUFA content was significantly higher in clear-water lakes ( $t$-test, Chironomidae: $t=-2.910$, df $=14, P<0.05$. Sida: $t=-2.965$, df $=8, P<0.05$ ) (Table 2).

\section{Discussion}

Our results show that lake browning influences both the community structure and the FA composition and content of invertebrates. The invertebrate community structure was different between the two lake types, supporting our first hypothesis. Lake type also affected the FA composition and content of Asellus, Sida, Heptagenia, Lestes, and Chironomidae. Shore type, however, had only a small influence on the FA composition of invertebrates.

Invertebrate community structure

Community structure of invertebrates in boreal lakes is shaped by many factors, e.g., lake area, total phosphorous (Heino, 2008) and DOC concentrations (Johnson \& Goedkoop, 2002; Aroviita et al., 2019). 
Table 2 The average proportions ( $\%$ of total FAs), content ( $\mu \mathrm{g} \mathrm{mg} \mathrm{DW}^{-1}$ ), and standard deviations $( \pm$ ) of FAs, and the $\omega 3 / \omega 6$ and DHA/ARA ratios of littoral invertebrates in humic and clear-water lakes

\begin{tabular}{|c|c|c|c|c|c|c|c|c|}
\hline \multirow[b]{2}{*}{ SAFAs } & \multicolumn{2}{|l|}{ Hydracarina } & \multicolumn{2}{|l|}{ Lestes } & \multicolumn{2}{|l|}{ Heptagenia } & \multicolumn{2}{|c|}{ Chironomidae } \\
\hline & Humic & Clear-water & Humic & Clear-water & Humic & Clear-water & Humic & Clear-water \\
\hline $12: 00$ & $1.9 \pm 1.9$ & $0.4 \pm 0.3$ & t.d & t.d & $0.6 \pm 0.5$ & $1.0 \pm 0.5$ & t.d & t.d \\
\hline $14: 00$ & $4.7 \pm 1.9$ & $3.0 \pm 0.5$ & $1.8 \pm 0.9$ & $2.1 \pm 0.8$ & $2.8 \pm 1.6$ & $3.5 \pm 0.9$ & $5.0 \pm 2.0$ & $3.7 \pm 1.0$ \\
\hline $15: 00$ & t.d & t.d & $0.6 \pm 0.4$ & $0.4 \pm 0.1$ & t.d & t.d & $1.2 \pm 0.8$ & $0.3 \pm 0.1$ \\
\hline $16: 00$ & $17.9 \pm 4.6$ & $16.1 \pm 2.4$ & $18.8 \pm 4.7$ & $18.8 \pm 2.6$ & $26.1 \pm 5.4$ & $27.0 \pm 3.3$ & $31.1 \pm 6.8$ & $21.5 \pm 1.5$ \\
\hline $17: 00$ & $1.3 \pm 0.7$ & $1.5 \pm 0.5$ & $1.4 \pm 0.4$ & $1.3 \pm 0.4$ & $0.8 \pm 0.3$ & $0.7 \pm 0.1$ & $2.5 \pm 1.1$ & $1.0 \pm 0.6$ \\
\hline $18: 00$ & $17.3 \pm 5.8$ & $20.3 \pm 4.2$ & $9.1 \pm 2.5$ & $8.2 \pm 1.2$ & $8.7 \pm 1.8$ & $7.7 \pm 0.5$ & $11.1 \pm 2.3$ & $6.9 \pm 2.9$ \\
\hline $20: 00$ & $0.8 \pm 0.2$ & 0.70 .1 & $0.6 \pm 0.4$ & $0.6 \pm 0.3$ & 0.0 & 0.0 & $1.1 \pm 0.5$ & $0.9 \pm 0.2$ \\
\hline $22: 00$ & t.d & t.d & t.d & t.d & $0.6 \pm 0.2$ & $0.4 \pm 0.1$ & t.d & t.d \\
\hline Total $(\%)$ & $43.9 \pm 9.3$ & $41.9 \pm 4.4$ & $32.3 \pm 3.8$ & $31.3 \pm 2.9$ & $39.7 \pm 6.2$ & $40.3 \pm 4.7$ & $52.5 \pm 10.5$ & $34.4 \pm 3.1$ \\
\hline SAFA $\left(\mu \mathrm{g} \mathrm{mg} \mathrm{DW}^{-1}\right)$ & $57.9 \pm 21.1$ & $48.8 \pm 26.5$ & $52.3 \pm 22.4$ & $47.5 \pm 22.8$ & $49.4 \pm 19.0$ & $70.6 \pm 13.5$ & $32.2 \pm 9.9$ & $32.8 \pm 11.6$ \\
\hline \multicolumn{9}{|l|}{ MUFAs } \\
\hline $14: 1$ & $1.3 \pm 1.1$ & $0.3 \pm 0.2$ & t.d & t.d & $0.5 \pm 0.3$ & $0.7 \pm 0.1$ & $0.3 \pm 0.7$ & $1.4 \pm 0.6$ \\
\hline $16: 1 \omega 9$ & t.d & t.d & t.d & t.d & t.d & t.d & $0.4 \pm 0.2$ & $0.6 \pm 0.2$ \\
\hline $16: 1 \omega 7$ & $16.0 \pm 4.4$ & $13.3 \pm 3.8$ & $9.1 \pm 3.5$ & $6.6 \pm 2.0$ & $18.8 \pm 5.0$ & $17.9 \pm 0.5$ & $9.4 \pm 3.0$ & $12.0 \pm 4.2$ \\
\hline $16: 1 \omega 5$ & t.d & t.d & t.d & t.d & $0.6 \pm 0.3$ & $0.7 \pm 0.3$ & $0.5 \pm 0.3$ & $0.5 \pm 0.2$ \\
\hline $18: 1 \omega 9$ & $15.5 \pm 3.7$ & $15.5 \pm 4.3$ & $10.5 \pm 1.8$ & $10.4 \pm 0.7$ & $7.2 \pm 1.2$ & $9.2 \pm 0.5$ & $10.6 \pm 2.6$ & $9.0 \pm 2.2$ \\
\hline $18: 1 \omega 7$ & $5.3 \pm 1.1$ & $6.1 \pm 1.4$ & $12.3 \pm 2.7$ & $11.1 \pm 1.1$ & $13.5 \pm 2.9$ & $13.7 \pm 0.6$ & $4.6 \pm 2.3$ & $3.7 \pm 1.7$ \\
\hline Total $(\%)$ & $38.1 \pm 4.6$ & $35.2 \pm 7.2$ & $31.9 \pm 3.8$ & $28.1 \pm 1.6$ & $40.5 \pm 2.1$ & $42.2 \pm 0.5$ & $26.5 \pm 3.4$ & $27.3 \pm 2.6$ \\
\hline MUFA $\left(\mu \mathrm{g} \mathrm{mg} \mathrm{DW}{ }^{-1}\right)$ & $53.9 \pm 24.5$ & $44.9 \pm 31.5$ & $53.6 \pm 26.9$ & $43.8 \pm 21.8$ & $\mathbf{5 0 . 1} \pm \mathbf{1 7 . 6}$ & $73.1 \pm 9.7$ & $17.3 \pm 7.6$ & $26.9 \pm 12.0$ \\
\hline \multicolumn{9}{|l|}{ PUFAs } \\
\hline $16: 2 \omega 4$ & t.d & t.d & t.d & t.d & $0.4 \pm 0.2$ & $0.7 \pm 0.2$ & $0.4 \pm 0.5$ & $1.3 \pm 0.9$ \\
\hline $16: 3 \omega 3$ & t.d & t.d & t.d & t.d & 0.0 & 0.0 & $0.2 \pm 0.4$ & $2.2 \pm 0.8$ \\
\hline $16: 3 \omega 4$ & t.d & t.d & t.d & t.d & t.d & t.d & $0.1 \pm 0.3$ & $0.6 \pm 0.5$ \\
\hline $18: 2 \omega 6$ & $6.7 \pm 6.9$ & $7.9 \pm 3.1$ & $7.6 \pm 4.3$ & $6.6 \pm 1.1$ & $3.1 \pm 1.4$ & $2.8 \pm 1.4$ & $6.9 \pm 3.6$ & $8.9 \pm 3.2$ \\
\hline $18: 3 \omega 3$ & $1.6 \pm 1.2$ & $4.8 \pm 3.0$ & $5.5 \pm 1.5$ & $6.0 \pm 1.2$ & $3.9 \pm 2.7$ & $2.5 \pm 1.1$ & $3.9 \pm 2.1$ & $9.8 \pm 2.6$ \\
\hline $18: 3 \omega 4$ & 0.0 & 0.0 & t.d & t.d & t.d & t.d & t.d & t.d \\
\hline $18: 4 \omega 3$ & t.d & t.d & $0.6 \pm 0.3$ & $1.4 \pm 0.7$ & t.d & t.d & $0.2 \pm 0.2$ & $1.4 \pm 1.1$ \\
\hline $20: 4 \omega 6$ & $1.0 \pm 1.2$ & $1.3 \pm 0.9$ & $5.5 \pm 1.5$ & $5.1 \pm 1.1$ & $2.6 \pm 1.3$ & $2.0 \pm 0.8$ & $1.4 \pm 1.5$ & $2.0 \pm 0.8$ \\
\hline $20: 5 \omega 3$ & $2.7 \pm 3.5$ & $3.8 \pm 1.6$ & $12.0 \pm 3.0$ & $16.0 \pm 2.5$ & $6.3 \pm 2.5$ & $5.5 \pm 2.0$ & $3.9 \pm 3.6$ & $8.8 \pm 1.6$ \\
\hline $22: 6 \omega 3$ & 0.0 & 0.0 & t.d & t.d & t.d & t.d & t.d & t.d \\
\hline Total $(\%)$ & $12.0 \pm 11.3$ & $17.8 \pm 7.7$ & $31.1 \pm 6.4$ & $35.0 \pm 4.2$ & $16.2 \pm 7.4$ & $13.5 \pm 5.4$ & $17.4 \pm 9.8$ & $35.2 \pm 4.7$ \\
\hline PUFA ( $\mu \mathrm{g} \mathrm{mg} \mathrm{DW}^{-1}$ ) & $27.0 \pm 37.6$ & $18.7 \pm 7.6$ & $51.2 \pm 23.9$ & $52.2 \pm 18.7$ & $20.6 \pm 11.5$ & $25.9 \pm 8.3$ & $13.2 \pm 11.7$ & $35.4 \pm 14.0$ \\
\hline \multicolumn{9}{|l|}{ Other } \\
\hline i13:0 & $0.9 \pm 1.5$ & 0.0 & t.d & t.d & t.d & t.d & 0.0 & 0.0 \\
\hline $\mathrm{i} 15: 0$ & 0.0 & $0.5 \pm 0.4$ & t.d & t.d & t.d & t.d & $0.8 \pm 0.4$ & $0.3 \pm 0.2$ \\
\hline Phytanate & t.d & t.d & t.d & t.d & t.d & t.d & t.d & t.d \\
\hline i17:0 & t.d & t.d & t.d & t.d & t.d & t.d & $0.6 \pm 0.5$ & $0.3 \pm 0.3$ \\
\hline ai17:0 & t.d & t.d & t.d & t.d & t.d & t.d & $0.5 \pm 0.6$ & $0.5 \pm 0.5$ \\
\hline Total $(\%)$ & $1.9 \pm 1.7$ & $1.5 \pm 1.0$ & $0.9 \pm 0.3$ & $1.2 \pm 0.4$ & $0.8 \pm 0.4$ & $0.7 \pm 0.3$ & $2.0 \pm 1.2$ & $1.1 \pm 0.9$ \\
\hline Total FAs $\left(\mu \mathrm{g} \mathrm{mg} \mathrm{DW}^{-1}\right)$ & $141.9 \pm 74.9$ & $114.5 \pm 58.2$ & $158.7 \pm 70.6$ & $145.5 \pm 63.4$ & $121.3 \pm 40.3$ & $171.2 \pm 23.6$ & $64.5 \pm 26.3$ & $96.1 \pm 36.2$ \\
\hline$\omega 3 / \omega 6$ & $0.7 \pm 0.5$ & $0.9 \pm 0.2$ & $1.5 \pm 0.4$ & $2.0 \pm 0.3$ & $1.7 \pm 0.4$ & $1.8 \pm 0.2$ & $0.9 \pm 0.3$ & $2.2 \pm 0.9$ \\
\hline \multirow[t]{2}{*}{ DHA/ARA } & 0.0 & 0.0 & 0.0 & 0.0 & 0.0 & 0.0 & 0.0 & 0.0 \\
\hline & \multicolumn{3}{|l|}{ Sida } & \multicolumn{3}{|c|}{ Asellus aquaticus } & Pallasea $q$ & uadrispinosa \\
\hline SAFAs & Humi & & ear-water & Humic & Cle & r-water & Clear-wate & \\
\hline $12: 00$ & 0.0 & 0. & & t.d & t.d & & t.d & \\
\hline $14: 00$ & $4.9 \pm$ & & \pm 0.7 & $2.3 \pm 0.8$ & $1.6=$ & 0.6 & $3.2 \pm 2.1$ & \\
\hline $15: 00$ & $1.7 \pm 0$ & & \pm 0.4 & t.d & t.d & & t.d & \\
\hline $16: 00$ & $25.3 \pm$ & & $2 \pm 2.1$ & $19.5 \pm 1.7$ & 19.9 & \pm 1.6 & $17.9 \pm 2.1$ & \\
\hline $17: 00$ & $1.1 \pm$ & & \pm 0.5 & t.d & t.d & & t.d & \\
\hline
\end{tabular}


Table 2 continued

\begin{tabular}{|c|c|c|c|c|c|}
\hline \multirow[b]{2}{*}{ SAFAs } & \multicolumn{2}{|l|}{ Sida } & \multicolumn{2}{|c|}{ Asellus aquaticus } & \multirow{2}{*}{$\begin{array}{l}\text { Pallasea quadrispinosa } \\
\text { Clear-water }\end{array}$} \\
\hline & Humic & Clear-water & Humic & Clear-water & \\
\hline $18: 00$ & $4.2 \pm 0.9$ & $3.6 \pm 0.4$ & $3.8 \pm 1.5$ & $4.9 \pm 0.9$ & $2.2 \pm 0.5$ \\
\hline $20: 00$ & 0.0 & 0.0 & t.d & t.d & t.d \\
\hline $22: 00$ & t.d & t.d & t.d & t.d & t.d \\
\hline Total $(\%)$ & $37.1 \pm 2.6$ & $31.6 \pm 2.1$ & $25.5 \pm 1.9$ & $26.5 \pm 1.5$ & $23.4 \pm 4.5$ \\
\hline SAFA $\left(\mu \mathrm{g} \mathrm{mg} \mathrm{DW}^{-1}\right)$ & $25.4 \pm 5.6$ & $30.0 \pm 5.0$ & $44.7 \pm 16.7$ & $23.8 \pm 11.1$ & $30.6 \pm 8.6$ \\
\hline \multicolumn{6}{|l|}{ MUFAs } \\
\hline $14: 1$ & 0.0 & 0.0 & t.d & t.d & t.d \\
\hline $16: 1 \omega 9$ & $1.2 \pm 0.2$ & $1.1 \pm 0.1$ & t.d & t.d & t.d \\
\hline $16: 1 \omega 7$ & $6.6 \pm 1.8$ & $3.9 \pm 1.0$ & $33.4 \pm 11.3$ & $13.4 \pm 5.6$ & $14.4 \pm 4.9$ \\
\hline $16: 1 \omega 5$ & $0.5 \pm 0.1$ & $0.5 \pm 0.2$ & $0.6 \pm 0.2$ & $0.8 \pm 0.2$ & t.d \\
\hline $18: 1 \omega 9$ & $7.4 \pm 1.4$ & $7.8 \pm 0.9$ & $11.6 \pm 2.3$ & $16.5 \pm 1.9$ & $19.3 \pm 1.5$ \\
\hline $18: 1 \omega 7$ & $7.8 \pm 0.7$ & $7.1 \pm 0.6$ & $6.1 \pm 1.9$ & $8.3 \pm 1.1$ & $4.8 \pm 1.0$ \\
\hline MUFA $\left(\mu \mathrm{g} \mathrm{mg} \mathrm{DW}{ }^{-1}\right)$ & $16.2 \pm 3.9$ & $19.6 \pm 3.6$ & $91.1 \pm 43.7$ & $34.3 \pm 16.7$ & $55.1 \pm 22.2$ \\
\hline \multicolumn{6}{|l|}{ PUFAs } \\
\hline $16: 2 \omega 4$ & t.d & t.d & $1.3 \pm 0.6$ & $0.5 \pm 0.5$ & t.d \\
\hline $16: 3 \omega 3$ & t.d & t.d & t.d & t.d & t.d \\
\hline $16: 3 \omega 4$ & 0.0 & 0.0 & t.d & t.d & t.d \\
\hline $18: 2 \omega 6$ & $5.7 \pm 0.5$ & $5.8 \pm 0.4$ & $4.4 \pm 1.5$ & $8.5 \pm 1.7$ & $5.7 \pm 1.4$ \\
\hline $18: 3 \omega 3$ & $8.9 \pm 2.2$ & $8.1 \pm 0.3$ & $2.6 \pm 1.4$ & $6.1 \pm 2.1$ & $3.2 \pm 1.0$ \\
\hline $18: 3 \omega 4$ & $4.3 \pm 1.6$ & $6.4 \pm 0.6$ & t.d & t.d & t.d \\
\hline $18: 4 \omega 3$ & 0.0 & 0.0 & t.d & t.d & $0.7 \pm 0.4$ \\
\hline $20: 4 \omega 6$ & $5.0 \pm 0.6$ & $6.2 \pm 0.7$ & $4.0 \pm 1.9$ & $5.5 \pm 1.7$ & $4.3 \pm 0.5$ \\
\hline $20: 5 \omega 3$ & $12.7 \pm 1.6$ & $16.4 \pm 1.4$ & $4.2 \pm 2.1$ & $7.0 \pm 1.2$ & $14.1 \pm 0.6$ \\
\hline $22: 6 \omega 3$ & $0.2 \pm 0.2$ & $1.2 \pm 0.5$ & $0.4 \pm 0.3$ & $0.8 \pm 0.2$ & $4.6 \pm 0.4$ \\
\hline Total $(\%)$ & $36.8 \pm 4.4$ & $44.1 \pm 1.5$ & $16.8 \pm 6.3$ & $28.3 \pm 4.1$ & $32.6 \pm 1.4$ \\
\hline PUFA ( $\mu \mathrm{g} \mathrm{mg} \mathrm{DW}^{-1}$ ) & $26.2 \pm 7.7$ & $43.9 \pm 9.1$ & $26.7 \pm 8.6$ & $25.1 \pm 14.4$ & $46.7 \pm 18.1$ \\
\hline \multicolumn{6}{|l|}{ Other } \\
\hline $\mathrm{i} 13: 0$ & 0.0 & 0.0 & t.d & t.d & 0.0 \\
\hline $\mathrm{i} 15: 0$ & $0.6 \pm 0.1$ & $0.5 \pm 0.1$ & t.d & t.d & t.d \\
\hline Phytanate & t.d & t.d & $0.9 \pm 0.4$ & $0.3 \pm 0.2$ & t.d \\
\hline i17:0 & 0.0 & 0.0 & t.d & t.d & t.d \\
\hline ai17:0 & 0.0 & 0.0 & t.d & t.d & t.d \\
\hline Total $(\%)$ & $0.6 \pm 0.1$ & 0.50 .1 & $0.9 \pm 0.4$ & $0.3 \pm 0.2$ & t.d \\
\hline Total FAs ( $\left.\mu \mathrm{g} \mathrm{mg} \mathrm{DW}{ }^{-1}\right)$ & $67.9 \pm 16.1$ & $93.5 \pm 16.9$ & $165.6 \pm 65.1$ & $84.5 \pm 42.1$ & $133.8 \pm 49.2$ \\
\hline$\omega 3 / \omega 6$ & $2.1 \pm 0.3$ & $2.2 \pm 0.2$ & $0.8 \pm 0.2$ & $1.0 \pm 0.1$ & $2.3 \pm 0.5$ \\
\hline DHA/ARA & $0.0 \pm 0.0$ & $0.2 \pm 0.1$ & $0.1 \pm 0.0$ & $0.2 \pm 0.0$ & $1.1 \pm 0.2$ \\
\hline
\end{tabular}

Student's $t$-test results for the statistically significant $(P \leq 0.05)$ results are highlighted t.d. Trace amounts

Both Asellus and Chironomidae were common taxa in our lakes, and together contributed $36 \%$ of the differences in the community structure between humic and clear-water lakes. This is no surprise considering the generalist nature and adaptability of Asellus (Sket, 1994) and the vast variability of the members of the family Chironomidae. Chironomidae is one of the most abundant and widely distributed insect families in freshwater ecosystems, and members of this family differ in their tolerance to extreme environmental conditions, e.g., acidity, salinity, and low oxygen concentrations (Pinder, 1986), which leads to differences in the chironomid assemblages between clearwater and humic lakes (Luoto, 2013). Chironomidae was the only family that was significantly more abundant in humic lakes. Chironomids in humic lakes might be detritivores since they prefer shallow water systems and high amount of organic matter. 


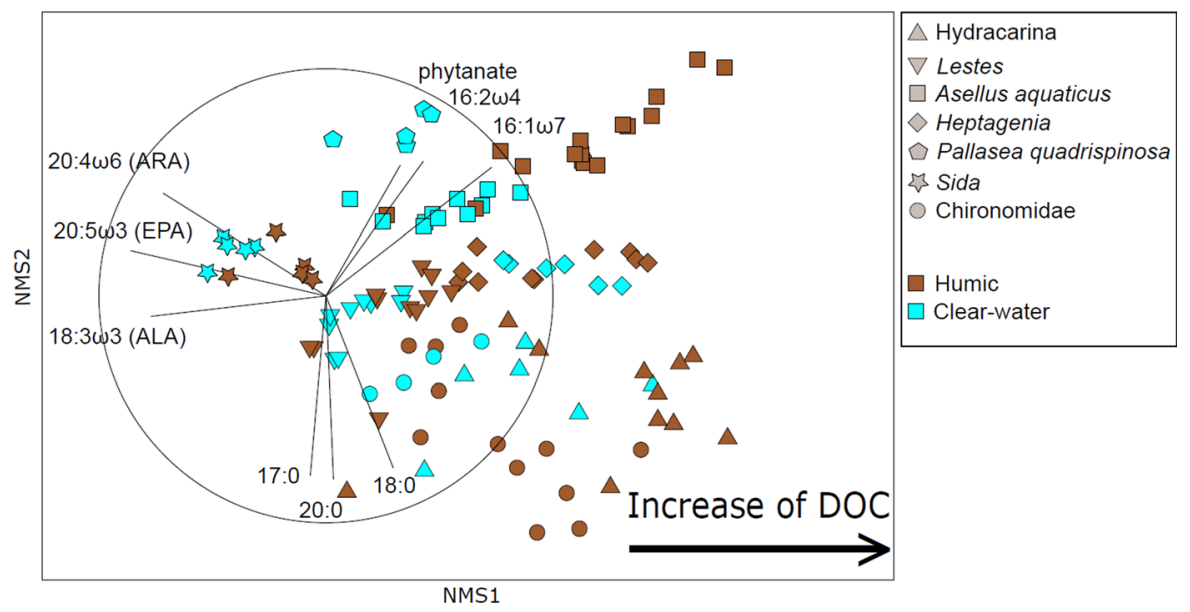

Fig. 2 Non-metric multidimensional scale (NMDS) ordination of the FA composition of littoral invertebrates. Littoral invertebrate taxa are presented with different markers. Samples from humic lakes are presented as brown and samples from clear-water lakes as light blue, respectively. The ordination was based on Euclidean distance. FAs that correlate strongly (Pearson $r>0.6$ ) with either of the axes are visualized with vectors. The $2 \mathrm{D}$ stress value for the ordination was 0.15 . The amount of DOC increases towards the right side of the ordination

Table 3 Proportions and standard deviations of different FAs and their contributions to the dissimilarities of the invertebrate FA composition between humic and clear-water lakes (SIMPER)

\begin{tabular}{|c|c|c|c|c|c|}
\hline \multirow[t]{2}{*}{ Taxa } & \multirow[t]{2}{*}{ FA } & \multicolumn{2}{|c|}{ Proportion (\%) } & \multirow{2}{*}{$\begin{array}{l}\text { Contribution to } \\
\text { dissimilarity (\%) }\end{array}$} & \multirow{2}{*}{$\begin{array}{l}\text { Cumulative } \\
\text { contribution }(\%)\end{array}$} \\
\hline & & Humic & Clear-water & & \\
\hline \multirow[t]{3}{*}{ Hydracarina } & $18: 2 \omega 6$ & $6.7 \pm 6.9$ & $7.9 \pm 3.1$ & 18 & 18 \\
\hline & $18: 3 \omega 3$ & $1.6 \pm 1.2$ & $4.8 \pm 3.0$ & 14 & 31 \\
\hline & $20: 5 \omega 3$ & $2.7 \pm 3.5$ & $3.8 \pm 1.6$ & 11 & 42 \\
\hline \multirow[t]{3}{*}{ Chironomidae } & $20: 5 \omega 3$ & $3.9 \pm 3.6$ & $8.8 \pm 1.6$ & 13 & 13 \\
\hline & $18: 3 \omega 3$ & $3.9 \pm 2.1$ & $9.8 \pm 2.6$ & 11 & 24 \\
\hline & $16: 3 \omega 3$ & $0.2 \pm 0.4$ & $2.2 \pm 0.8$ & 10 & 34 \\
\hline \multirow[t]{4}{*}{ Heptagenia } & $18: 3 \omega 3$ & $3.9 \pm 2.7$ & $2.5 \pm 1.1$ & 17 & 17 \\
\hline & $16: 0$ & $26.1 \pm 5.4$ & $27.0 \pm 3.3$ & 13 & 30 \\
\hline & $20: 5 \omega 3$ & $6.3 \pm 2.5$ & $5.5 \pm 2.0$ & 12 & 42 \\
\hline & $16: 1 \omega 7$ & $18.8 \pm 5.0$ & $17.9 \pm 0.5$ & 10 & 52 \\
\hline \multirow[t]{4}{*}{ Lestes } & $16: 1 \omega 7$ & $9.1 \pm 3.5$ & $6.6 \pm 2.0$ & 19 & 19 \\
\hline & $20: 5 \omega 3$ & $12.0 \pm 3.0$ & $16.0 \pm 2.5$ & 16 & 35 \\
\hline & $18: 2 \omega 6$ & $7.6 \pm 4.3$ & $6.6 \pm 1.1$ & 13 & 48 \\
\hline & $16: 0$ & $18.8 \pm 4.7$ & $18.8 \pm 2.6$ & 12 & 59 \\
\hline \multirow[t]{5}{*}{ Sida } & $22: 6 \omega 3$ & $0.2 \pm 0.2$ & $1.2 \pm 0.5$ & 19 & 19 \\
\hline & $16: 1 \omega 7$ & $6.6 \pm 1.8$ & $3.9 \pm 1.0$ & 17 & 36 \\
\hline & $18: 3 \omega 4$ & $4.3 \pm 1.6$ & $6.4 \pm 0.6$ & 13 & 49 \\
\hline & $20: 5 \omega 3$ & $12.7 \pm 1.6$ & $16.4 \pm 1.4$ & 11 & 60 \\
\hline & $16: 0$ & $25.3 \pm 1.5$ & $21.2 \pm 2.1$ & 10 & 70 \\
\hline Asellus aquaticus & $16: 1 \omega 7$ & $33.4 \pm 11.3$ & $13.4 \pm 5.6$ & 58 & 58 \\
\hline
\end{tabular}

FAs with a contribution $\geq 10 \%$ are listed here 


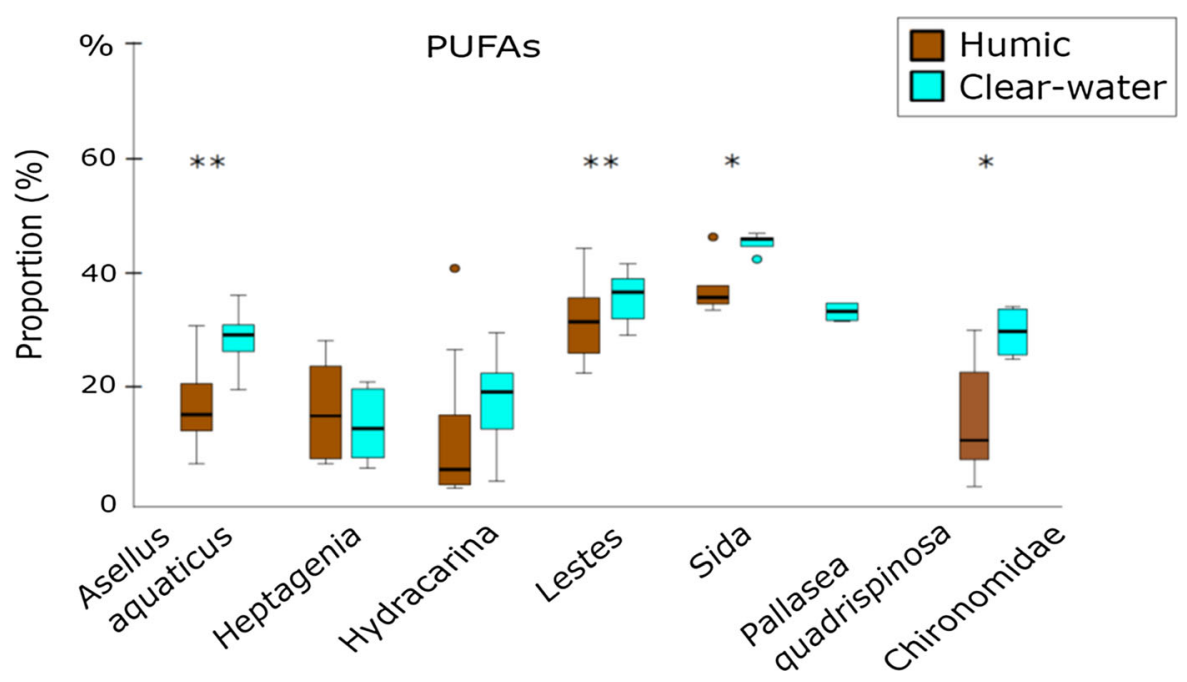

Fig. 3 Proportion of PUFAs relative to the total FAs of littoral invertebrates. Statistically significant differences have been marked with big asterisks, so that $* P<0.05$, and $* * P<0.01$, respectively. Proportions from humic lakes are presented as brown and the proportions from clear-water lakes as light blue, respectively. The boxes represent the median, and 25 th and 75 th quantiles, and the whiskers represent the smallest observation greater than or equal to lower hinge $-1.5 \times$ interquartile range and the largest observation less than or equal to upper hinge $+1.5 \times$ interquartile range. Circles represent the smallest observations less than lower hinge $-1.5 \times$ interquartile range and the biggest observations greater than upper hinge $+1.5 \times$ interquartile range (outlier)

Table 4 Contributions of different variables to the differences in the FA composition between humic and clear-water lakes in invertebrates (DistLM)

\begin{tabular}{|c|c|c|c|c|c|}
\hline Taxa & Variable & SS & Pseudo- $F$ & $P$ & Proportion explained (\%) \\
\hline Hydracarina & $\mathrm{C} / \mathrm{N}$ lake water & 0.16 & 3.14 & $<0.05$ & 17 \\
\hline Chironomidae & Secchi depth (m) & 0.29 & 4.70 & 0.005 & 25 \\
\hline \multirow[t]{4}{*}{ Lestes } & Mean depth of the lake (m) & 0.06 & 7.51 & $<0.001$ & 21 \\
\hline & Total N $\left(\mu \mathrm{g}^{-1}\right)$ & 0.06 & 4.03 & $<0.05$ & 19 \\
\hline & Peatland $(\%)$ & 0.05 & 4.18 & $<0.01$ & 17 \\
\hline & Secchi depth (m) & 0.04 & 5.30 & 0.001 & 12 \\
\hline Heptagenia & $\operatorname{DOC}\left(\mu \mathrm{g}^{-1}\right)$ & 0.10 & 6.65 & $<0.05$ & 26 \\
\hline \multirow[t]{3}{*}{ Sida } & Mean depth of the lake (m) & 0.06 & 9.07 & 0.0001 & 53 \\
\hline & Agriculture (\%) & 0.01 & 4.93 & $<0.05$ & 13 \\
\hline & Lake area $\left(\mathrm{km}^{2}\right)$ & 0.01 & 2.34 & $<0.05$ & 12 \\
\hline \multirow[t]{2}{*}{ Asellus aquaticus } & $\mathrm{C} / \mathrm{N}$ lake water & 0.74 & 31.54 & 0.0001 & 56 \\
\hline & Total $\mathrm{P}\left(\mu \mathrm{g} 1^{-1}\right)$ & 0.13 & 7.18 & $<0.01$ & 9 \\
\hline
\end{tabular}

$P$-values for the statistical significance of each variable are presented. Only statistically significant variables $(P \leq 0.05)$ are presented here. For variables, see SI, Table S2

SS sum of squares

Conversely, filter feeders prefer clear-water conditions (Kivilä et al., 2019). This demonstrates the need for a higher level of taxonomic resolution in determining the effects of lake browning on littoral invertebrate community structures.
Plecoptera as a whole and families from Plecoptera (Capniidae) and Ephemeroptera (Baetidae) were significantly more common in clear-water lakes. Moreover, Pallaseidae and Hydropsychidae were completely absent in humic lakes. Pallaseidae are 
mostly found in large, clear-water lakes (Särkkä et al., 1990). This is most likely related to their intolerance to acidic conditions (Økland \& Økland, 1986). Humic lakes have a lower calcium availability due to lower pH (Drzymulska et al., 2015). Amphipods need calcium during ecdysis (Zehmer et al., 2002), and the rate of calcium uptake during this process is dependent on calcium levels (Alstad et al., 1999) and pH (Malley, 1980). Altogether, $\mathrm{pH}$ of the lake water positively correlates with invertebrate species richness on a pH range of 4-7 (Hämäläinen \& Huttunen, 1990). Other acid-sensitive taxa include gastropods (Gastropoda) and Ephemeroptera (Økland \& Økland, 1986).

Oxygen concentration of lake water is also one of the most important factors shaping invertebrate community structure. Humic and other organic substances increase the consumption of oxygen in lakes due to increased bacterial activity (Jones, 1992; Ask et al., 2012). Decreased oxygen concentration will be particularly harmful for less tolerant taxa, such as Plecoptera, Ephemeroptera, and Amphipoda (Fochetti \& Tierno De Figueroa, 2008). We suggest that both the lower $\mathrm{pH}$ and decreased oxygen concentration in humic lakes are the reason for the lower abundance of Plecoptera and Baetidae and absence of Pallaseidae and Hydropsychidae. There are, however, variations within the members of the family Hydropsychidae for oxygen and pollution sensitivity (Vuori \& Parkko 1996; Stuijfzand et al. 1999; Savic et al., 2013).

Humic lakes are generally smaller and shallower than clear-water lakes (Nürnberg \& Shaw, 1999). Lake size has been shown to affect the invertebrate community structure because larger lakes offer a wider selection of habitats (Heino, 2008). Habitat type has been shown to affect the invertebrate community composition more than water chemistry. Smaller lakes offer less variation in habitat types and are therefore expected to be dominated by generalists (Tolonen, 2004). The high percentage of Chironomidae in humic lake invertebrate community partly supports this.

Fatty acid composition of invertebrates

Proportions of FAs showed different patterns in the sampled invertebrates. When moving up the food chain, the proportion of SAFAs tends to decrease, whereas the proportion of $\mathrm{C}_{20-22}$ PUFAs increases (Lau et al., 2012). This is partly demonstrated in our data as well because predatory Lestes had a relatively low proportion of SAFAs and a high proportion of PUFAs. This is also supported by the results of Makhutova et al. (2016). However, Hydracarina, which were likely predators, showed a completely opposite trend, having a high proportion of SAFAs and a low proportion of PUFAs. Unfortunately, studies about the FA composition of Hydracarina are scarce, so we have little to compare with. We also found hardly any differences in the FA composition of Hydracarina between the two lake types, so it might indicate a strong phylogenetic control on their FA composition.

There is evidence that the FA composition of Chironomidae follows that of their diet, but they also actively modify dietary FAs (Strandberg et al., 2020a). They contained a lot of SAFAs, especially the ones sampled from humic lakes. This supports the findings of Kara et al. (2012), who found high levels of SAFAs from Chironomidae during all seasons. According to Makhutova et al. (2017) the PUFA content of Chironomidae is variable, and it is controlled by both phylogeny and feeding strategy.

Sida had a high proportion of PUFAs with EPA being the most common one. FA composition of Cladocera has been found to reflect that of their diet (Brett et al., 2006). They also retain dietary EPA and ARA (Taipale et al., 2011) and actively biosynthesize $\mathrm{C}_{20}$ PUFAs from $\mathrm{C}_{22}$ PUFAs (Strandberg et al., 2014). EPA has been shown to support the growth and reproduction of Daphnia (Müller-Navarra et al., 2000; Persson \& Vrede, 2006; Ravet \& Brett, 2006) so it might hold importance for Sida as well. Sida also contained ARA, but the studies about its necessity, at least in Daphnia reproduction, have yielded varying results (Becker \& Boersma, 2005; Ravet et al., 2012).

Pallasea had a significantly higher proportion of DHA compared to the other taxa. In general, predatory invertebrate larvae contain higher amounts of DHA compared to ARA (Ahlgren et al., 2009), but it should be noted that insects contain less or completely lack DHA, compared to crustaceans (Guo et al., 2016). This pattern is clearly visible in our data as well. DHA could be related to the nervous system, which is rich in it (Lauritzen et al., 2001) and may also indicate active synthesis of DHA from its shorter chain analogs (Maazouzi et al., 2007). DHA is a limiting FA in fish growth (Sargent et al., 1999; Ballantyne et al., 2003), so DHA-rich Pallasea can be considered a high- 
quality food source for them. Amphipods can be an important food source for many fish species, e.g., brown trout (Salmo trutta; Linnaeus, 1758), also several macroinvertebrate predators prefer them (Macneil et al., 1999). Pallasea also contained a lot of EPA. Their diets consist of algae and small invertebrates (Hill, 1988), which are probably the sources of it. Also, Gammaridae selectively utilize EPA-rich particles from the sediments and water column (Makhutova et al., 2003), so same might be true for Pallasea.

Asellus contained a lot of MUFAs and relatively low amounts of PUFAs. Lau et al. (2012) showed that Asellus were rich in biomarker FAs of terrestrialderived detritus $(18: 1 \omega 9,18: 2 \omega 6)$, bacteria $(18: 1 \omega 7)$, and diatoms (16:107). These FAs were also common in our Asellus. They also had a low $\omega 3 / \omega 6$ ratio, which might indicate the use of terrestrial-derived organic matter or other low-quality food sources.

Heptagenia had a relatively low $\omega 3 / \omega 6$ ratio $(\sim 2)$, with reported ratios of Ephemeroptera being as high as 6 (Bell et al., 1994; Sushchik et al., 2003; Torres-Ruiz et al., 2007), which suggests differences in the FA composition of different members of Ephemeroptera. The $\omega 3 / \omega 6$ ratios have been used to identify allochthonous vs. autochthonous food sources, with ratios $>1$ usually indicative of predominantly autochthonous food sources (Torres-Ruiz et al., 2007; Guo et al., 2016) and ratios $<1$ allochthonous food sources and poor nutritional condition (Taipale et al., 2014).

The $\omega 3 / \omega 6$ ratios were relatively low $(\sim 1-2)$ in the invertebrate taxa analyzed here, but within the range $(<1$ to 7$)$ generally found in invertebrate taxa (Ahlgren et al., 2009). Asellus have been shown to selectively scrape the surface of submerged leaves, ingesting fungal mycelia (Bloor, 2011). Typically, the most abundant PUFA in fungi is 18:2 $\omega 6$, and thus their $\omega 3 / \omega 6$ ratio is also low (Stahl \& Klug, 1996). Certain littoral resources, specifically leaf litter of terrestrial plants, also contain a high amount of $\omega 6$-PUFAs, and thus have a low $\omega 3 / \omega 6$ ratio (Harris \& James, 1965; Torres-Ruiz \& Wehr, 2010). Invertebrates rely on benthic algae as their main food source in low-DOC lakes, whereas in high-DOC lakes they may utilize relatively more phytoplankton and allochthonous organic carbon (Premke et al., 2010). However, leaf litter is not nutritionally adequate for all benthic invertebrates, e.g., Gammaridae excreted ingested fragments of the leaf litter and did not assimilate them (Bogatov et al., 2021).

Fatty acids in humic and clear-water lake invertebrates

In this study, taxon explained $65 \%$ of the variation in FA composition, which supports previous findings (Lau et al., 2012; Vesterinen et al., 2020). Despite the strong phylogenetic control, lake type significantly influenced the FA composition of Lestes, Chironomidae, Sida, and Asellus. Lake type also significantly influenced the FA content of Heptagenia and Asellus. Finally, we found only small differences in the FA composition of invertebrates between vegetated and unvegetated shores, challenging our third hypothesis.

The proportions of several individual and total PUFAs were significantly affected by the lake type. When significant differences were found, the proportion of PUFAs was always lower in samples from humic lakes compared to samples from clear-water lakes. Only exception was the FA 16:204 in Asellus. The proportion of MUFAs was significantly different in Asellus between the two lake types, which is largely explained by higher proportion of 16:1 107 in humic lakes compared to clear-water lakes. It also explained most of the differences in the FA composition of Asellus between the two lake types. High amounts of $\mathrm{C}_{16}$ MUFAs and low amounts of PUFAs have been connected to the consumption of bacteria (Kiyashko et al., 2004). According to the results by Pond et al. (1997) 16:204 might also be of bacterial origin, so Asellus most likely utilized bacteria in humic lakes. The $\mathrm{C} / \mathrm{N}$ ratio of lake water explained most of the variation in the FA composition of Asellus between the two lake types. Our previous study found that lake water chemistry was strongly correlated with lake catchment characteristics in our study lakes; lakes with high $\mathrm{C} / \mathrm{N}$ ratios were strongly correlated with high DOC values and proportion of peatland in the catchment area (Strandberg et al., 2016). Thus, the lower proportion of PUFAs and lower $\omega 3 / \omega 6$ ratio in humic lakes compared to clear-water lakes is probably related to the utilization of terrestrial-derived organic matter or other low-quality food source.

Lake type had significant effects on the FA composition and content of Chironomidae in our study. Our results showed that the proportions of SAFAs and PUFAs and the $\omega 3 / \omega 6$ ratio differed 
between the two lake types. This could indicate that detrital allochthonous matter is a more common food source for chironomids in humic lakes, whereas in clear-water lakes their diets might consist more of algae. Makhutova et al. (2017) also found that the FA composition of Chironomidae differs between different species. Since lake type also affects the community structure of Chironomidae (Luoto, 2013), we realize that lake type specific differences in FA profiles in Chironomidae may results from different community composition and may not be directly due to differences between the lake types.

Together with Chironomidae, lake type significantly influenced the proportion of PUFAs and the $\omega 3 /$ $\omega 6$ ratio of Sida. Environmental factors accounting the most to the differences in the FA composition between the two lake types in these two taxa (Secchi depth, mean depth) had a strong negative correlation with the phosphorous and DOC concentration of lake water (Strandberg et al., 2016). The FA explaining most of the differences between the two lake types was EPA in Chironomidae and DHA in Sida. The differences in the FA composition of Chironomidae and Sida between the two lake types might be related to the changes in the algal communities between the two lake types. Chironomidae had a significantly higher percentage of markers for green algae (16:3 13 and 16:403, Makhutova et al., 2016) in clear-water lakes compare to the humic lakes. In Chironomidae, the explanation for the higher proportion of SAFAs in humic lakes might be related to the utilization of relatively more abundant allochthonous leaf litter compared to clear lakes, since leaf litter mainly contain SAFAs (Brett et al., 2009; Bec et al., 2010; Taipale et al., 2014). Also, the $\omega 3 / \omega 6$ ratios support the idea of higher proportions of allochthonous food items in the diets of Chironomidae in humic lakes. Some feeding guilds might obtain EFAs more efficiently, depending on the available food items. Filter feeders, for example, might suffer from the increased abundance of poor-quality food sources (regarding EFAs), since they do not select their food items. This might explain the differences in the FA composition of Sida between the two lake types.

In Lestes, the differences in the FA composition between the two lake types were mainly found in PUFAs and $\omega 3 / \omega 6$ ratio. Mean depth of the lake contributed the most to the differences between the two lake types. This factor also had a strong negative correlation with the phosphorous and DOC concentration. Differences in the $\omega 3 / \omega 6$ ratio between the two lake types might be related to the quality of prey organisms. Zygoptera have broad diets, so changes in relative abundance of poor- and high-quality food items might reflect their FA composition.

DOC concentration was the only significant factor explaining the differences in the FA composition of Heptagenia. However, since there were only small differences in the FA composition of Heptagenia between humic and clear-water lakes, it indicates that phylogeny is more important driver in establishing the FA composition of Heptagenia. Effects of shore type did not affect the FA composition of invertebrates, besides Heptagenia. We hypothesized that different habitats contain different food sources, leading to differences in the FA compositions of invertebrates. Most invertebrate taxa are considered opportunistic regarding their food sources (Tierno de Figueroa et al., 2019) and can utilize several types of food (Friberg \& Jacobsen, 1994), which might lead to differences in their FA composition. It is possible that the shore types in our study contained similar food sources, and thus clear differences in the FA compositions were not detectable. Vegetated shores generally contain a wider range of potential food sources, including epiphytic algae (Jones et al., 1998), decaying macrophytes (Smock \& Harlowe, 1983), and allochthonous leaf litter (Weatherhead \& James, 2001). Why the differences in the FA composition between the shore types were only present in Heptagenia, remains unclear. One possible explanation could be, that there are taxaspecific habitat preferences in different species within the genus Heptagenia.

\section{Conclusions}

With intensified land-use practices and ongoing climate change, the amount of terrestrial DOC in lake waters is expected to rise. Our study indicates that lake browning may alter the littoral food webs in two ways, (1) by changing invertebrate community structure and (2) by decreasing the proportion and content of PUFAs in several invertebrate taxa. Our results on invertebrates are supported by the observed significantly lower EFA content of predatory perch (Perca fluviatilis; Linnaeus, 1758, length $>250 \mathrm{~mm}$ ) in humic lakes compared with those in clear-water lakes 
(Strandberg et al., 2016). Thus, lake browning may lower the amount of PUFAs in fish used in human consumption. Our results indicate that lake browning might negatively influence the transfer and/or accumulation of EFAs in boreal lake food webs, all the way up to humans.

Acknowledgements We thank Aslak Eronen, Kari Ratilainen, and Tuomo Nielsen for their help in collecting the littoral invertebrate samples. We would also like to thank three anonymous reviewers for their constructive criticism, which improved the final version of the manuscript.

Funding Open access funding provided by University of Eastern Finland (UEF) including Kuopio University Hospital. The corresponding author would like to thank Olvi Foundation and Jenny and Antti Wihuri Foundation for their grants, which supported the writing of this article. The study was also supported by the Academy of Finland Grants ( $\# 263350$ and \#310450) to Paula Kankaala.

Data availability The littoral macroinvertebrate community data that support the findings of this study are openly available in the Finnish Environment Institute (SYKE) HERTTAdatabase at www.syke.fi/avoindata. The fatty acid data that support the findings of this study are available from the corresponding author upon reasonable request. Other data is given as Supplementary Information.

\section{Declarations}

Conflict of interest The authors declare no conflict of interest.

Open Access This article is licensed under a Creative Commons Attribution 4.0 International License, which permits use, sharing, adaptation, distribution and reproduction in any medium or format, as long as you give appropriate credit to the original author(s) and the source, provide a link to the Creative Commons licence, and indicate if changes were made. The images or other third party material in this article are included in the article's Creative Commons licence, unless indicated otherwise in a credit line to the material. If material is not included in the article's Creative Commons licence and your intended use is not permitted by statutory regulation or exceeds the permitted use, you will need to obtain permission directly from the copyright holder. To view a copy of this licence, visit http://creativecommons.org/licenses/by/4.0/.

\section{References}

Ahlgren, G., L. Lundstedt, M. Brett \& C. Forsberg, 1990. Lipid composition and food quality of some freshwater phytoplankton for cladoceran zooplankters. Journal of Plankton Research 12: 809-818.

Ahlgren, G., T. Vrede \& W. Goedkoop, 2009. Fatty acid ratios in freshwater fish, zooplankton and zoobenthos - are there specific optima? In Arts, M., M. Brett \& M. Kainz (eds), Lipids in Aquatic Ecosystems Springer, Dordrecht: 147-178.

Alstad, N., L. Skardal \& D. Hessan, 1999. The effect of calcium concentration on the calcification of Daphnia magna. Limnology and Oceanography 44: 2011-2017.

Anneville, O., I. Domaizon, O. Kerimoglu, F. Rimet \& S. Jacquet, 2015. Blue-green algae in a "Greenhouse century"? New insights from field data on climate change impacts on cyanobacteria abundance. Ecosystems 18: 441-458.

Aroviita, J., S. Mitikka \& S. Vienonen, 2019. Status classification and assessment criteria of surface waters in the third river basin management cycle. Suomen Ympäristökeskuksen raportteja 37.

Arts, M. \& C. Kohler, 2009. Health and condition in fish: the influence of lipids on membrane competency and immune response. In Arts, M., M. Brett \& M. Kainz (eds), Lipids in Aquatic Ecosystems Springer, Dordrecht: 237-255.

Ask, J., J. Karlsson \& M. Jansson, 2012. Net ecosystem production in clear-water and brown-water lakes. Global Biogeochemical Cycles. https://doi.org/10.1029/ 2010 GB003951.

Ballantyne, A., M. Brett \& D. Schindler, 2003. The importance of dietary phosphorus and highly unsaturated fatty acids for sockeye (Oncorhynchus nerka) growth in Lake Washington - a bioenergetics approach. Canadian Journal of Fisheries and Aquatic Sciences 60: 12-22.

Bec, A., M. Perga, C. Desvilettes \& G. Bourdier, 2010. How well can the fatty acid content of Lake Seston be predicted from its taxonomic composition? Freshwater Biology 55: 1958-1972.

Becker, C. \& M. Boersma, 2005. Differential effects of phosphorus and fatty acids on Daphnia magna growth and reproduction. Limnology and Oceanography 50: 388-397.

Bell, J., C. Ghioni \& J. Sargent, 1994. Fatty acid compositions of 10 freshwater invertebrates which are natural food organisms of Atlantic salmon parr (Salmo salar): a comparison with commercial diets. Aquaculture 128: 301-313.

Bergström, A. \& J. Karlsson, 2019. Light and nutrient control phytoplankton biomass responses to global change in northern lakes. Global Change Biology 25: 2021-2029.

Bloor, M., 2011. Dietary preference of Gammarus pulex and Asellus aquaticus during a laboratory breeding programme for ecotoxicological studies. International Journal of Zoology 2011: 294394.

Bogatov, V., N. Sushchik, O. Makhutova, A. Kolmakova \& M. Gladyshev, 2021. Allochthonous and autochthonous food sources for zoobenthos in a forest stream. Russian Journal of Ecology 52: 253-256.

Brett, M., D. Müller-Navarra, A. Ballantyne, J. Ravet \& C. Goldman, 2006. Daphnia fatty acid composition reflects that of their diet. Limnology and Oceanography 51: 2428-2437.

Brett, M., M. Kainz, S. Taipale \& M. Seshan, 2009. Phytoplankton, not allochthonous carbon, sustains herbivorous zooplankton production. Proceedings of the National Academy of Sciences of the United States of America 106: 21197-21201.

Christie, W., 1993. Preparation of ester derivatives of fatty acids for chromatographic analysis. In Christie, W. (ed), Lipid Methodology, Vol. 2. Oily Press, Dundee: 69-111. 
Clarke, K., 1993. Non-parametric multivariate analyses of changes in community structure. Australian Journal of Ecology 18: 117-143.

Cummins, K., 1973. Trophic relations of aquatic insects. Annual Review of Entomology 18: 183-206.

Di Sabatino, A., R. Gerecke \& P. Martin, 2000. The biology and ecology of lotic water mites (Hydrachnidia). Freshwater Biology 44: 47-62.

Drzymulska, D., M. Fiłoc, M. Kupryjanowicz, K. Szeroczyńska \& P. Zieliński, 2015. Postglacial shifts in lake trophic status based on a multiproxy study of a humic lake. The Holocene 25: 495-507.

Fairchild, G., 1981. Movement and microdistribution of Sida crystallina and other littoral microcrustacea. Ecology 62: 1341-1352.

Fochetti, R. \& J. Tierno De Figueroa, 2008. Global diversity of stoneflies (Plecoptera; Insecta) in freshwater. Hydrobiologia 595: 365-377.

Folch, J., M. Lees \& G. Sloane Stanley, 1957. A simple method for the isolation and purification of total lipids from animal tissues. The Journal of Biological Chemistry 226: 497-509.

Friberg, N. \& D. Jacobsen, 1994. Feeding plasticity of two detritivore-shredders. Freshwater Biology 32: 133-142.

Galloway, A. \& M. Winder, 2015. Partitioning the relative importance of phylogeny and environmental conditions on phytoplankton fatty acids. PLoS ONE 10: e0130053.

Gladyshev, M., N. Sushchik, S. Shulepina, A. Ageev, O. Dubovskaya, A. Kolmakova \& G. Kalachova, 2016. Secondary production of highly unsaturated fatty acids by zoobenthos across rivers contrasting in temperature. River Research and Applications 6: 1252-1263.

Guo, F., M. Kainz, F. Sheldon \& S. Bunn, 2016. The importance of high-quality algal food sources in stream food webs current status and future perspectives. Freshwater Biology 61: 815-831.

Gutseit, K., O. Berglund \& W. Graneli, 2007. Food quality for Daphnia in humic and clear waterlakes. Freshwater Biology 52: 344-356.

Hämäläinen, H. \& P. Huttunen, 1990. Estimation of acidity in streams by means of benthic invertebrates: evaluation of two methods. In Kauppi, P., P. Anttila \& K. Kenttämies (eds), Acidification in Finland Springer, Berlin: 1051-1070.

Harris, R. \& A. James, 1965. Linoleic, $\alpha$-linolenic acid biosynthesis in plant leaves and a green alga. Biochimica et Biophysica Acta/Lipids and Lipid Metabolism 106: 456-464.

Hayden, B., J. Myllykangas, R. Rolls \& K. Kahilainen, 2017. Climate and productivity shape fish and invertebrate community structure in Subarctic lakes. Freshwater Biology 62: 990-1003.

Heino, J., 2008. Patterns of functional biodiversity and function-environment relationships in lake littoral macroinvertebrates. Limnology and Oceanography 53: 1446-1455.

Hill, C., 1988. Life cycle and spatial distribution of the amphipod Pallasea quadrispinosa in a lake in northern Sweden. Holoarctic Ecology 11: 298-304.

Hongve, D., G. Riise \& J. Kristiansen, 2004. Increased colour and organic acid concentrations in Norwegian forest lakes and drinking water - a result of increased precipitation? Aquatic Sciences 66: 231-238.
Johnson, R. \& W. Goedkoop, 2002. Littoral macroinvertebrate communities: spatial scale and ecological relationships. Freshwater Biology 47: 1840-1854.

Jones, R., 1992. The influence of humic substances on lacustrine planktonic food chains. Hydrobiologia 229: 73-91.

Jones, J., B. Moss \& J. Young, 1998: Interactions between periphyton, nonmolluscan invertebrates, and fish in standing freshwaters. In Jeppesen, E., Ma. Søndergaard, Mo. Søndergaard \& K. Christoffersen (eds), The Structuring Role of Submerged Macrophytes in Lakes. Springer, New York: 69-90. https://doi.org/10.1007/978-1-46120695-8_4.

Jyväsjärvi, J., M. Järvinen \& H. Hämäläinen, 2014. Spatial community concordance of summer phytoplankton and profundal macroinvertebrates in boreal lakes. Canadian Journal of Fisheries and Aquatic Sciences 71: 1776-1783.

Kara, T., A. Tellioglu \& S. Aydin, 2012. Fatty acid composition of Chironomidae larvae in different seasons. Asian Journal of Chemistry 24: 5309-5312.

Khrennikov, V., I. Baryshev, Y. Shustov, V. Pavlov \& N. Ilmast, 2007. Zoobenthos of salmon rivers in the Kola Peninsula and Karelia (north east Fennoscandia). Ecohydrology and Hydrobiology 7: 71-77.

Kivilä, E., T. Luoto, M. Rantala, M. Kiljunen, M. Rautio \& L. Nevalainen, 2019. Environmental controls on benthic food web functions and carbon resource use in Subarctic lakes. Freshwater Biology 64: 643-658.

Kiyashko, S., A. Imbs, T. Narita, V. Svetashev \& E. Wada, 2004. Fatty acid composition of aquatic insect larvae Stictochironomus pictulus (Diptera: Chironomidae): evidence of feeding upon methanotrophic bacteria. Comparative Biochemistry and Physiology, Part B: Biochemistry and Molecular Biology 139: 705-711.

Kritzberg, E., 2017. Centennial-long trends of lake browning show major effect of afforestation. Limnology and Oceanography Letters 2: 105-112.

Lau, D., T. Vrede, J. Pickova \& W. Goedkoop, 2012. Fatty acid composition of consumers in boreal lakes - variation across species, space and time. Freshwater Biology 57: 24-38.

Lau, D., W. Goedkoop \& T. Vrede, 2013. Cross-ecosystem differences in lipid composition and growth limitation of a benthic generalist consumer. Limnology and Oceanography 58: 1149-1164.

Lauritzen, L., H. Hansen, M. Jorgensen \& K. Michaelsen, 2001. The essentiality of long chain n-3 fatty acids in relation to development and function of the brain and retina. Progress in Lipid Research 40: 1-94.

Lepistö, A., M. Futter \& P. Kortelainen, 2014. Almost 50 years of monitoring shows that climate, not forestry, controls long-term organic carbon fluxes in a large boreal watershed. Global Change Biology 20: 1225-1237.

Lindholm, M., M. Eie, D. Hessen, J. Johansen, K. Weiby \& J. Thaulow, 2018. Effects of water browning on freshwater biodiversity: the case of the predatory phantom midge Chaoborus nyblaei. Hydrobiologia 813: 33-40.

Luoto, T., 2013. Dystrophy in determining midge community composition in boreal lakes. Ecoscience 20: 391-398.

Maazouzi, C., G. Masson, M. Izquierdo \& J. Pihan, 2007. Fatty acid composition of the amphipod Dikerogammarus villosus: feeding strategies and trophic links. Comparative 
Biochemistry and Physiology Part A, Molecular and Integrative Physiology 147: 868-875.

Macneil, C., J. Dick \& R. Elwood, 1999. The dynamics of predation on Gammarus spp. (Crustacea: Amphipoda). Biological Reviews 74: 375-395.

Makhutova, O., G. Kalachova \& M. Gladyshev, 2003. A comparison of the fatty acid composition of Gammarus lacustris and its food sources from a freshwater reservoir, Bugach, and the saline Lake Shira in Siberia, Russia. Aquatic Ecology 37: 159-167.

Makhutova, O., N. Sushchik, M. Gladyshev, A. Ageev, E. Pryanichnikova \& G. Kalachova, 2011. Is the fatty acid composition of freshwater zoobenthic invertebrates controlled by phylogenetic or trophic factors? Lipids 46 : 709-721.

Makhutova, O., S. Shulepina, T. Sharapova, O. Dubovskaya, N. Sushchik \& M. Baturina, 2016. Content of polyunsaturated fatty acids essential for fish nutrition in zoobenthos species. Freshwater Science 35: 1222-1234.

Makhutova, O., E. Borisova, S. Shulepina, A. Kolmakova \& N. Sushchik, 2017. Fatty acid composition and content in chironomid species at various life stages dominating in a saline Siberian lake. Contemporary Problems of Ecology 3: 230-239.

Malley, D., 1980. Decreased survival and calcium uptake by the crayfish Orconectes virilis in low $\mathrm{pH}$. Canadian Journal of Fisheries and Aquatic Sciences 37: 364-372.

Martin-Creuzburg, D., E. Von Elert \& K. Hoffmann, 2008. Nutritional constraints at the cyanobacteria-Daphnia magna interface: the role of sterols. Limnology and Oceanography 53: 456-468.

Monteith, D., J. Stoddard, C. Evans, H. de Wit, M. Forsius, T. Høgåsen, A. Wilander, B. Skjelkvåle, D. Jeffries, J. Vuorenmaa, B. Keller, J. Kopácek \& J. Vesely, 2007. Dissolved organic carbon trends resulting from changes in atmospheric deposition chemistry. Nature 450: 537-540.

Moog, O., 2002. Fauna aquatica Austriaca. Wasserwirtschaftskataster, Bundesministerium fur Land- und Forstwirtschaft, Umwelt and Wasserwirtschaft (A Comprehensive Species Inventory of Austrian Aquatic Organisms with Ecological Notes), 2nd ed. Federal Ministry of Agriculture, Forestry, Environment and Water Management, Vienna:

Müller-Navarra, D., M. Brett, A. Liston \& C. Goldman, 2000. A highly unsaturated fatty acid predicts carbon transfer between primary producers and consumers. Nature 403: 74-77.

Nieminen, M., M. Koskinen, S. Sarkkola, A. Laurén, A. Kaila, O. Kiikkilä, T. Nieminen \& L. Ukonmaanaho, 2015. Dissolved organic carbon export from harvested peatland forests with differing site characteristics. Water, Air, and Soil Pollution. https://doi.org/10.1007/s11270-015-24440 .

Nürnberg, G. \& M. Shaw, 1999. Productivity of clear and humic lakes: nutrients, phytoplankton, bacteria. Hydrobiologia 382: $97-112$.

Økland, J. \& K. Økland, 1986. The effects of acid deposition on benthic animals in lakes and streams. Experientia 42: 471-486.
Persson, J. \& T. Vrede, 2006. Polyunsaturated fatty acids in zooplankton: variation due to taxonomy and trophic position. Freshwater Biology 51: 887-900.

Pinder, L., 1986. Biology of freshwater Chironomidae. Annual Review of Entomology 31: 1-23.

Pond, D., D. Dixon, M. Bell, A. Fallick \& J. Sargent, 1997. Occurrence of $16: 2(n-4)$ and $18: 2(n-4)$ fatty acids in the lipids of the hydrothermal vent shrimps Rimicaris exoculata and Alvinocaris markensis: nutritional and trophic implications. Marine Ecology Progress Series 156: 167-174.

Premke, K., J. Karlsson, K. Steger, C. Gudasz, E. von Wachenfeldt \& L. Tranvik, 2010. Stable isotope analysis of benthic fauna and their food sources in boreal lakes. Journal of the North American Benthological Society 29: 1339-1348.

Ravet, J. \& M. Brett, 2006. Phytoplankton essential fatty acid and phosphorus content constraints on Daphnia somatic growth and egg production. Limnology and Oceanography 51: 2438-2452.

Ravet, J., J. Persson \& M. Brett, 2012. Threshold dietary polyunsaturated fatty acid concentrations for Daphnia pulex growth and reproduction. Inland Waters 2: 199-209.

Reuss, N., L. Hamerlik, G. Velle, A. Michelsen, O. Pedersen \& K. Brodersen, 2013. Stable isotopes reveal that chironomids occupy several trophic levels within West Greenland lakes: implications for food web studies. Limnology and Oceanography 58: 1023-1034.

Sargent, J., J. Bell, R. Henderson \& D. Tocher, 1995. Requirement criteria for essential fatty acids. Journal of Applied Ichthyology 11: 183-198.

Sargent, J., G. Bell, L. McEvoy, D. Tocher \& A. Estevez, 1999. Recent developments in the essential fatty acid nutrition of fish. Aquaculture 177: 191-199.

Särkkä, J., J. Meriläinen \& J. Hynynen, 1990. The distribution of relict crustaceans in Finland: new observations and some problems and ideas concerning relicts. Annales Zoologici Fennici 27: 221-225.

Savic, A., V. Ranfldelovic, M. Dorfldevic, B. Karadžic, M. Dokic \& J. Krpo-Cetkovic, 2013. The influence of environmental factors on the structure of caddisfly (Trichoptera) assemblage in the Nišava River (Central Balkan Peninsula). Knowledge and Management of Aquatic Ecosystems. https://doi.org/10.1051/kmae/201305.

Senar, O., I. Creed \& C. Trick, 2021. Lake browning may fuel phytoplankton biomass and trigger shifts in phytoplankton communities in temperate lakes. Aquatic Sciences. https:// doi.org/10.1007/s00027-021-00780-0.

Shustov, Y., I. Baryshev \& E. Belyakova, 2012. Specific features of the feeding of juvenile Atlantic salmon (Salmo salar L.) in the Subarctic Varzuga River and its small tributaries (Kola Peninsula). Inland Water Biology 5: 288-292.

Sket, B., 1994. Distribution of Asellus aquaticus (Crustacea: Isopoda: Asellidae) and its hypogean populations at different geographic scales, with a note on Proasellus istrianus. Hydrobiologia 287: 39-47.

Smock, L. \& K. Harlowe, 1983. Utilization and processing of freshwater wetland macrophytes by the detritivore Asellus forbesi. Ecology 64: 1556-1565. 
Stahl, P. \& M. Klug, 1996. Characterization and differentiation of filamentous fungi based on fatty acid composition. Applied and Environmental Microbiology 62: 4136-4146.

Strandberg, U., S. Taipale, M. Kainz \& M. Brett, 2014. Retroconversion of docosapentaenoic acid (n-6): an alternative pathway for biosynthesis of arachidonic acid in Daphnia magna. Lipids 49: 591-595.

Strandberg, U., M. Palviainen, A. Eronen, S. Piirainen, A. Laurén, J. Akkanen \& P. Kankaala, 2016. Spatial variability of mercury and polyunsaturated fatty acids in the European perch (Perca fluviatilis) - implications for riskbenefit analyses of fish consumption. Environmental Pollution 219: 305-314.

Strandberg, U., M. Hiltunen, N. Rissanen, S. Taipale, J. Akkanen \& P. Kankaala, 2020a. Increasing concentration of polyunsaturated fatty acids in browning boreal lakes is driven by nuisance alga Gonyostomum. Ecosphere. https:// doi.org/10.1002/ecs2.3189.

Strandberg, U., J. Vesterinen, T. Ilo, J. Akkanen, M. Melanen \& P. Kankaala, 2020b. Fatty acid metabolism and modifications in Chironomus riparius. Philosophical Transactions of the Royal Society B Biological Sciences. https://doi.org/ 10.1098/rstb.2019.0642.

Stuijfzand, S., S. Engels, E. van Ammelrooy \& M. Jonker, 1999. Caddisflies (Trichoptera: Hydropsychidae) used for evaluating water quality of large European rivers. Archives of Environmental Contamination and Toxicology 36: 186-192.

Sushchik, N., M. Gladyshev, A. Moskvichova, O. Makhutova \& G. Kalachova, 2003. Comparison of fatty acid composition in major lipid classes of the dominant benthic invertebrates of the Yenisei River. Comparative Biochemistry and Physiology, Part B: Biochemistry and Molecular Biology 134: 111-122.

Taipale, S., M. Kainz \& M. Brett, 2011. Diet-switching experiment shows rapid accumulation and preferential retention of highly unsaturated fatty acids in Daphnia. Oikos 120: 1674-1682.

Taipale, S., U. Strandberg, U. Peltomaa, A. Galloway, A. Ojala \& M. Brett, 2013. Fatty acid composition as biomarkers of freshwater microalgae: analysis of 37 strains of microalgae in 22 genera and in seven classes. Aquatic Microbial Ecology 71: 165-178.

Taipale, S., M. Kainz \& M. Brett, 2014. A low w-3:w-6 ratio in Daphnia indicates terrestrial resource utilization and poor nutritional condition. Journal of Plankton Research 37: 596-610.

Taipale, S., K. Vuorio, U. Strandberg, K. Kahilainen, M. Järvinen, M. Hiltunen, E. Peltomaa \& P. Kankaala, 2016. Lake eutrophication and brownification downgrade availability and transfer of essential fatty acids for human consumption. Environment International 96: 156-166.
Thrane, J., D. Hessen \& T. Andersen, 2014. The absorption of light in lakes: negative impact of dissolved organic carbon on primary production. Ecosystems 17: 1040-1052.

Tierno de Figueroa, J., M. López-Rodríguez \& M. Villar-Argaiz, 2019. Spatial and seasonal variability in the trophic role of aquatic insects: an assessment of functional feeding group applicability. Freshwater Biology 64: 954-966.

Tolonen, K., 2004. Patterns in diversity and assemblages of lake littoral macroinvertebrates in relation to abiotic and biotic factors. PhD Thesis, University of Joensuu.

Torres-Ruiz, M. \& J. Wehr, 2010. Changes in the nutritional quality of decaying leaf litter in a stream based on fatty acid content. Hydrobiologia 651: 265-278.

Torres-Ruiz, M., J. Wehr \& A. Perrone, 2007. Trophic relations in a stream food web: importance of fatty acids for macroinvertebrate consumers. Journal of the North American Benthological Society 26: 509-522.

Vasconcelos, F., S. Diehl, P. Rodríguez, P. Hedström, J. Karlsson \& P. Byström, 2019. Bottom-up and top-down effects of browning and warming on shallow lake food webs. Global Change Biology 25: 504-521.

Vesterinen, J., O. Keva, K. Kahilainen, U. Strandberg, M. Hiltunen, P. Kankaala \& S. Taipale, 2020. Nutritional quality of littoral macroinvertebrates and pelagic zooplankton in Subarctic lakes. Limnology and Oceanography. https://doi. org/10.1002/lno.11563.

Vuori, K. \& M. Parkko, 1996. Assessing pollution of the River Kymijoki via hydropsychid caddisflies. Archiv für Hydrobiologie 136: 171-190.

Walker, I., C. Fernando \& C. Paterson, 1985. Associations of Chironomidae (Diptera) of shallow, acid, humic lakes and bog pools in Atlantic Canada, and a comparison with an earlier paleoecological investigation. Hydrobiologia 120: 11-22.

Weatherhead, M. \& M. James, 2001. Distribution of macroinvertebrates in relation to physical and biological variables in the littoral zone of nine New Zealand lakes. Hydrobiologia 462: 115-129.

Weyhenmeyer, G., Y. Prairie \& L. Tranvik, 2014. Browning of boreal freshwaters coupled to carbon-iron interactions along the aquatic continuum. PLoS ONE. https://doi.org/ 10.1371/journal.pone.0088104.

Zehmer, J., S. Mahon \& G. Capelli, 2002. Calcium as a limiting factor in the distribution of the amphipod Gammarus pseudolimnaeus. The American Midland Naturalist 148: 350-362.

Publisher's Note Springer Nature remains neutral with regard to jurisdictional claims in published maps and institutional affiliations. 